2000s-48

\title{
Occupational Gender Composition and Wages in Canada: 1987-1988
}

\author{
Michael Baker, Nicole M. Fortin
}

Série Scientifique

Scientific Series

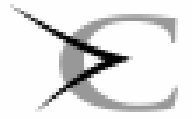

Centre internaiversinaire de recherche

en analyse des organisaticas

Montréal

Octobre 2000 


\section{CIRANO}

Le CIRANO est un organisme sans but lucratif constitué en vertu de la Loi des compagnies du Québec. Le financement de son infrastructure et de ses activités de recherche provient des cotisations de ses organisationsmembres, d'une subvention d'infrastructure du ministère de la Recherche, de la Science et de la Technologie, de même que des subventions et mandats obtenus par ses équipes de recherche.

CIRANO is a private non-profit organization incorporated under the Québec Companies Act. Its infrastructure and research activities are funded through fees paid by member organizations, an infrastructure grant from the Ministère de la Recherche, de la Science et de la Technologie, and grants and research mandates obtained by its research teams.

\section{Les organisations-partenaires / The Partner Organizations}

-École des Hautes Études Commerciales

-École Polytechnique

-Université Concordia

-Université de Montréal

-Université du Québec à Montréal

-Université Laval

-Université McGill

-MEQ

-MRST

-Alcan Aluminium Ltée

-AXA Canada

-Banque Nationale du Canada

-Banque Royale du Canada

-Bell Québec

-Bombardier

-Bourse de Montréal

-Développement des ressources humaines Canada (DRHC)

-Fédération des caisses populaires Desjardins de Montréal et de l'Ouest-du-Québec

-Hydro-Québec

-Imasco

-Industrie Canada

-Pratt \& Whitney Canada Inc.

-Raymond Chabot Grant Thornton

-Ville de Montréal

(C) 2000 Michael Baker et Nicole M. Fortin. Tous droits réservés. All rights reserved.

Reproduction partielle permise avec citation du document source, incluant la notice ().

Short sections may be quoted without explicit permission, provided that full credit, including ( $)$ notice, is given to the source.

Ce document est publié dans l'intention de rendre accessibles les résultats préliminaires de la recherche effectuée au CIRANO, afin de susciter des échanges et des suggestions. Les idées et les opinions émises sont sous l'unique responsabilité des auteurs, et ne représentent pas nécessairement les positions du CIRANO ou de ses partenaires.

This paper presents preliminary research carried out at CIRANO and aims at encouraging discussion and comment. The observations and viewpoints expressed are the sole responsibility of the authors. They do not necessarily represent positions of CIRANO or its partners.

\section{ISSN 1198-8177}




\title{
Occupational Gender Composition and Wages in Canada: 1987-1988*
}

\author{
Michael Baker ${ }^{\dagger}$, Nicole M. Fortin
}

Résumé / Abstract

Dans cet article, nous dressons un portrait complet, de la fin des années 1980, de la ségrégation professionnelle fondée sur le sexe au Canada et de ses répercussions sur les salaires. Notre analyse révèle que les estimés de la "pénalité salariale »dans les emplois féminins sont influencés par le choix de méthodes d'estimations et des spécifications fonctionnelles. Nos estimés les plus robustes indiquent que pour les femmes au Canada la pénalité reliée aux emplois féminins est généralement plus faible que celle trouvée aux États-Unis. Bien que nous trouvons des résultats hétérogènes en considérant différents groupes de travailleurs, en moyenne le lien entre le taux de féminité des professions et les salaires des femmes est faible et généralement pas statistiquement significatif.

In this paper, we provide a comprehensive picture, circa the late 1980's, of occupational gender segregation in Canada and its consequences for wages. Our analysis reveals sensitivity of the estimated penalty to "female work" to both specification and estimation strategy. Our preferred estimates indicate that the wage penalties for women in female jobs in Canada are generally smaller than penalties in the United States. Of particular note, while there is some heterogeneity across worker groups, on average the link between female wages and gender composition is small and generally not statistically significant.

\footnotetext{
* Corresponding Author: Nicole M. Fortin, CIRANO, 2020 University Street, $25^{\text {th }}$ floor, Montréal, Qc, Canada H3A 2A5 Tel.: (514) 985-4000 Fax: (514) 985-4039 email: nifortin@interchange.ubc.ca Forthcoming in the Canadian Journal of Economics. We thank Angelo Morino for many helpful discussions. Some of the analysis reported in this paper was previously circulated under the title "Gender Composition and Wages: Why Is Canada Different from the United States?". We have benefited from comments on that manuscript and/or the present paper from Dwayne Benjamin, Morley Gunderson, Guy Lacroix, Thomas Lemieux, Marianne Page, Roberta Robb, Gary Solon, and seminar participants at the 1998 CEA's, the 1999 AEA's, the University of British Columbia, and McMaster University. We would like to thank Garnett Picot, René Morissette, and Steve Roller, for facilitating our access to the Canadian data. We also thank Ali Bejaoui for excellent research assistance. Finally, we are grateful for the assistance of Wayne Roth and Wayne Silver with the CCDO coding, as well as the work of secretarial staff at CRDE typing CCDO jobs characteristics for more than 6,500 seven-digit occupations. Financial support for this research was provided by CIRANO, Human Resources Development Canada, the Social Sciences and Humanities Research Council of Canada (Baker: Grants \#410-96-0187 and \#410-99-0112, Fortin: Grants \#410-96-0651 and \#410-99-0959), FCAR Québec and a General Research Grant at the University of Toronto. All opinions expressed in this paper are the authors'.

${ }^{\dagger}$ University of Toronto

¥ University of British Columbia, CRDE and CIRANO
} 
Mots Clés : Équité salariale, salaire égal pour travail de valeur comparable, taux de féminité des professions, segmentation des professions, estimateur à deux étapes

Keywords: Pay equity, comparable worth, gender composition, occupational gender segregation, wage determination, two-step estimator

JEL: J71, J78 


\section{INTRODUCTION}

Canada has some of the most extensive comparable worth/pay equity legislation in the world. It covers public sector workers at the federal level and in most provinces. Recently pro-active policies have been extended to the private sectors of Ontario and Quebec, provinces that contained 62 percent of the population of Canada in $1996 .^{2}$ One might infer that the source of this legislative activity is a battery of studies documenting systematically lower wages in "female jobs". In fact, this is not the case. While there is a large literature documenting the gender wage gap in this country, there is, to our knowledge, next to no evidence that female jobs are poorly paid in Canada. ${ }^{3}$ There is extensive evidence, however, of a negative effect of the "femaleness" of occupations on wages in other parts of the world, particularly the United States. The basis of the Canadian legislative initiatives, therefore, would appear to be the experiences of other countries.

The evidence from the United States provides important information on the determinants of low wages in "female jobs", as well as limitations of public policy in this area. For example, Johnson and Solon (1986) show that female-male wage differences within occupations are substantially inter-firm/industry and thus outside the purview of most comparable worth legislation. ${ }^{4}$ Macpherson and Hirsch (1995) argue that much of the relationship between wages and the femaleness of occupations can be accounted for by detailed job characteristics, and differences in the unobserved skills of workers in male and female

${ }^{2}$ Source: 1996 Canadian census. See http://www.statcan.ca/english/census96/.

${ }^{3}$ See, Kidd and Shannon (1994), Baker, Benjamin, Desaulniers and Grant (1995) and most recently Drolet (1999) for evidence on gender wage and earnings differentials in Canada. Baker, Benjamin, Desaulniers and Grant (1993) attempt to estimate the correlation of wages with the femaleness of employment in Canada as of 1985. Their analysis is limited by the lack of appropriate occupational data. Fillmore (1990) finds a very small effect of percentage female on average occupational female earnings. Finally, Reilly and Wirjanto (1999) find a substantial penalty to gender composition of the establishment.

${ }^{4}$ This is consistent with studies such as Carrington and Troske (1995) that document gender segregation across firms and the role it plays in the gender wage gap. 
jobs. That said, advances in other research areas suggest that these sorts of inferences can be enriched by corroborating or contrasting evidence from other jurisdictions. In the case at hand, the empirical evidence is overwhelmingly drawn from the U.S. experience. An investigation of the Canadian data, therefore, widens the empirical perspective, and brings a new set of facts to bear on theories of wages in female jobs.

In this paper we provide a comprehensive picture, circa the late 1980s, of the relationship between occupational gender segregation in Canada and wages. ${ }^{5}$ We document the sensitivity of our estimates to various estimation strategies used in the literature, and to the specification of the additional conditioning variables. The contribution of occupational characteristics (from the Canadian Classification and Dictionary of Occupations (CDDO)) is considered, an innovation that has proved important in the U.S. literature (Macpherson and Hirsch 1995). We also accommodate potential non-linearities in the relationship between wages and gender composition using kernel regressions. This provides a (graphically) clear illustration of how the gender wage gap varies with the "femaleness" of jobs. Separate estimates of the status of female jobs are presented across workers distinguished by full/part time work, union status, firm size, and industrial sectors, as well as other demographic characteristics. Finally, we exploit the panel dimension of our data in an attempt to discover the contribution of unobserved characteristics to the wages in female jobs.

Our choice of time period is deliberate. In the late 1980s, there were few public sector,

${ }^{5}$ In a previous paper (Baker and Fortin 1999b) we investigate the wages of women in female jobs in Canada in the context of a US/Canada comparison. As explained below, we do not use the Canadian occupational codes in that comparison, which results in an analysis at a higher level of occupational aggregation. We also focus on the roles of unionization and wage effects for "public goods" sector jobs, two factors that prove important in the cross-country context. Relative to that paper, the analysis here considers a much wider array of explanatory variables, including detailed occupational characteristics, studies the sensitivity of the estimates to various estimation strategies, investigates heterogeneity in the relationship between wages and gender composition, and provides panel estimates as well as a full set of estimates for the wages of men. 
and no private sector, pay equity initiatives in Canada. The labour market was largely free of the effects of comparable worth. In contrast, by the late 1990 s pay equity is almost synonymous with the public sector, and is soon to cover the private sectors of Canada's two largest provincial labour markets. Evaluation of this flurry of legislative activity requires careful documentation of the wages in female jobs before these laws took effect. Estimates of the wage penalty in female jobs from this period provide, by some measures, an upper bound on the potential benefits of these initiatives. Therefore, the analysis we offer in this paper can serve as a baseline for future work in the area.

Our investigation uncovers some surprising differences in the Canadian case. Most of our estimates of the wage penalties for female jobs are smaller than corresponding estimates for the United States. Most importantly, the estimates of the penalty for Canadian women are consistently small and generally not significantly different from zero.

We begin in Section 2 surveying the legislative environment in Canada at the time of the analysis. The description of the data and its salient features are presented in Section 3. Section 4 outlines our econometric strategy for estimating the correlation of occupational gender composition and wages in the presence of grouped data. The results are presented in Section 5. In Section 6 we examine the relationship between the "wage penalties" in female jobs and the gender wage gap. We conclude in Section 7.

\section{The Legislative Environment}

The objective of pay equity legislation is to eliminate the effect of occupational gender segregation on wages. Empirically, this means the elimination of any systematic relationship between wages and the femaleness of employment, net of differences in "allowable" productivity related characteristics across individuals in different occupations. ${ }^{6}$ This rela-

${ }^{6}$ Some studies, such as Blau and Beller (1988), investigate the relationship between the femaleness of occupations and wages using dummy variables for male dominated occupations and mixed 
tionship is the primary focus of the study. While a comprehensive summary of pay equity in Canada is beyond the scope of this paper, it is necessary to consider the pay equity policies in effect in Canada at the time of our analysis (1987 and 1988). These policies have obvious implications for the interpretation of wage levels that we observe in female jobs.

Canada has been called a world leader in comparable worth (e.g., Weiner and Gunderson (1990)). ${ }^{7}$ That said, in our period of interest many provincial pay equity initiatives were quite recent, and should have had limited effects in the labour market. Two of the longer standing policies in place in the late 1980s were in Quebec and in the federal jurisdiction. The concept of pay equity was introduced to the human rights codes of these jurisdictions in 1977 and 1978, respectively. Both of these pay equity initiatives were complaint-based. Under complaint based legislation, investigation of (and possible restitution for) low wages in female jobs is only initiated if an employee complaint is registered. Therefore, the onus is on workers. The alternative is a proactive program, in which employers erect a pay equity plan that typically involves 1) the identification of predominantly female and predominantly male jobs, 2) the assignment of numerical scores to jobs reflecting their levels of skill, effort, responsibility, and the working conditions, 3) the comparison of the numerical scores of female and male jobs in relation to salary rates, and 4) pay adjustments for 'undervalued' female jobs. Here the onus is on the employers.

The Quebec legislation in principle covered all employees in the province working outside the federal jurisdiction. This seemingly wide-ranging legislation was rarely used, however, with only 37 cases heard by 1990 (Weiner and Gunderson 1990). The federal legislation covers both the (broader) federal public sector and federally regulated industries

occupations. Yet other studies (Killingsworth 1990) combine dummy variables with percentage female. We focus on "percentage female" for comparability with the more recent studies.

${ }^{7}$ Good summaries of the state of Canadian legislation around our sample period can be found in Symes (1990) and Weiner and Gunderson (1990). The current legislative environment is summarized in CCH Canadian Limited (1997). 
(e.g. transportation, banking). ${ }^{8}$ It also appears, however, to have been seldom used in the period preceding our years of interest. By 1990 roughly 20 cases, affecting just 5000 workers, had been heard under the legislation (Weiner and Gunderson 1990). ${ }^{9}$

Pay equity in other jurisdictions circa the late 1980's was quite recent and typically restricted to the public sector. Manitoba passed the first pro-active pay equity legislation in 1985 . The first awards were to be made by September 1987, which is one of our sample years. Since the implementation of this legislation proceeded on schedule, it is possible that its initial effects, if any, will be captured in our data. The next initiatives were in Ontario in 1987 and in Nova Scotia and Prince Edward Island in 1988. ${ }^{10}$ The implementation plans for this legislation suggest that their effects are likely outside our sample period. ${ }^{11}$

Therefore, in the late 1980's Canada's labour market might be considered largely free of any effects of pay equity policies, save for the rarely used federal and Quebec laws, and any initial effects of Manitoba's legislation. ${ }^{12}$ Of course, the 1990 s have seen many initiatives such as the implementation of pro-active pay equity in the private sector in Ontario, and more recently in Quebec. ${ }^{13}$ By choosing our sample period prior to this legislation, we are

${ }^{8}$ These also include crown corporations.

${ }^{9}$ See Symes (1990) and Cihon (1988) for further evidence that the federal and Quebec pay equity legislation of this period was seldom tested.

${ }^{10}$ Newfoundland had a non-legislated pay equity initiative as of 1988 .

${ }^{11}$ For example, the first awards under the Ontario legislation were scheduled for January 1, 1990.

${ }^{12}$ It is possible that the threat effect of the Quebec and federal legislation led some firms in these jurisdictions to change their pay structures. While we lack the data to examine the evolution of the effect of gender composition in different jurisdictions over the 1980's, we can examine any provincial heterogeneity in that effect as of 1987/88. Our analysis by provinces for 1987 and 1988 combined (to get larger sample sizes) reveals that the effect of the occupational femaleness rate, PFEM, on female wages is generally small and not statistically significant ranging from -0.051 to 0.113 with standard errors around 0.06 . The signs of the coefficients are not obviously related to the existence or forthcoming implementation of provincial pay equity legislation: Newfoundland (0.021), Nova Scotia (0.113), New Brunswick (-0.009), Quebec (-0.051), Ontario (-0.040), Manitoba (-0.001), Saskatchewan (0.094) Alberta (0.018), British Columbia (0.048).

${ }^{13}$ The first pay equity awards in the Ontario private sector were scheduled for January 1, 1991, while the Quebec legislation passed in 1996 will not be implemented until 2001. 
able to isolate its target.

\section{Data and Descriptive Evidence}

The data for this study are drawn from the cross-sectional Labour Market Activity Survey (LMAS) for 1987 and 1988, and from the longitudinal LMAS for 1988-89. We include all wage and salary workers between the ages of 16 and 69 , who are not full-time students and are earning more than $\$ 1.00$ an hour. ${ }^{14}$ As explained below, additional variables measuring gender composition are obtained from Census data and variables measuring occupational characteristics are coded from the CCDO. The LMAS is a retrospective survey covering year-round labour market activity. The longitudinal files include information on all jobs held over a three year period. To mimic a point-in-time survey, we select job information as of the third week of November. ${ }^{15}$ Wages are obtained from the main job at this time; they are the actual hourly wage for workers paid by the hour and the usual hourly earnings for other workers. The resulting sample sizes for the 1987 and 1988 cross-section samples are given in table 1, which also provides the average wage levels in 1988 Canadian dollars by gender. ${ }^{16}$

We measure the femaleness of occupations as the proportion of employment that is female in the corresponding four-digit detailed occupation (PFEM). To minimize measurement error, PFEM is constructed from the 1991 Canadian census (the reference year is 1990). ${ }^{17}$ In each case, we sample individuals who are employed in the reference week and

${ }^{14}$ We exclude full-time students because they are excluded under most legislation, when they work in connection to their studies. This exclusion is also made for comparability with other studies (Macpherson and Hirsch 1995).

${ }^{15}$ That particular choice of week was dictated by comparability with other surveys in the context of a larger research project.

${ }^{16}$ The LMAS provides sample weights that are used in the analysis.

${ }^{17}$ The Canadian 1980 SOC occupational codes available in the LMAS are also available in the 1991 census. 
otherwise satisfy the same selection criteria as for the LMAS. ${ }^{18}$ The Canadian four-digit occupation codes, comprising approximately 500 categories, are roughly of the same order of aggregation as U.S. three-digit codes. There are, however, some differences in the coding of occupations across the two countries that should be considered in any attempt to compare the results of this study to those in the U.S. literature. In Baker and Fortin (1999b) we provide a Canada/United States comparison of the wage penalty in female job's using a cross-country consistent set of occupation codes. ${ }^{19}$

We note that an evaluation of the Canadian evidence has not been possible in the past because public use data sets include occupation codes at a much higher level of aggregation. For example, Baker et al. (1993) provide some evidence of the relationship of wages with the femaleness of employment in Canada as of 1985. Their results, however, are from Survey of Consumer Finance data in which occupation is available at only the 2-digit level (i.e., 47 categories). Furthermore, they demonstrate that estimates of the relationship are sensitive to the aggregation of the occupational categories. ${ }^{20}$ We were fortunate to gain access to versions of the census and LMAS files that include the more detailed occupation codes. $^{21}$

The LMAS also provides a rich array of personal and job characteristics which we exploit in the analysis. Because it is a job-based survey, in our panel analysis we are able

${ }^{18}$ For example, we exclude individuals from the Yukon and Northwest Territories from the Canadian census since they are not surveyed in the LMAS.

${ }^{19}$ Any differences in "comparable" estimates between these papers are due the use of a different set of occupation codes. For example, in the Canada/United States comparison, we used 275 occupation codes for women in 1988, whereas here, we have 378 codes.

${ }^{20}$ They compare estimates of the correlation of wages with the gender composition of employment in SCF data using, alternatively, 1-digit (i.e., Canadian Census) and 2-digit occupational codes. The correlation's for females are $0.354(0.028)$ and $0.055(0.034)$ from the 1-digit and 2-digit codes respectively (standard errors in parentheses). Similar changes are reported for the correlations for males.

${ }^{21}$ In addition to detailed occupation codes, our Canadian data also contain a single year age variable instead of the usual 5-year classes available in the LMAS. 
to identify both job changers and occupation switchers. Previous panel studies of gender composition and wages (Macpherson and Hirsch 1995) simply use changes in occupation to identify movers. There is the possibility, therefore, that measurement error in the occupation variable is driving some of the identifying variation in the U.S. data.

In table 1 we provide an overview of the gender composition of occupations and its consequences for wages in Canada in 1987 and 1988. Across all jobs, the femaleness rate, $P F E M$, is about 67 percent for women, while for men it is 25 percent. As a point of comparison, we also report corresponding statistics for the United States. These are calculated from the Outgoing Rotation Group samples of the Current Population Survey (CPS-ORG) for 1987 and 1988, using similar sample exclusions and U.S. 3-digit occupation codes. The average PFEM in the United States is very similar to the rates observed in Canada, as well as to the rates reported in Macpherson and Hirsch (1995) for these years.

The statistics are also reported for "female", "mixed" and "male" jobs. Women make up approximately 45 percent of the workforce; thus jobs comprising between $(45-15=)$ 30 percent and $(45+15=) 60$ percent of women are said to be mixed. In 1988 , these jobs represented 33 percent of female employment in Canada and 30 percent in the United States. Managerial jobs and work in food preparation and processing are typical mixed jobs. Predominantly female jobs are defined as those with a femaleness rate of 60 percent or higher. ${ }^{22}$ In 1988, they represented 57 percent of female employment in Canada and 61 percent in the United States. Clerical and health care works are typical female jobs. Predominantly male jobs are those with a femaleness rate of at most 30 percent. In 1988 , they represented 9.8 percent of female employment in Canada and 8.5 in the United States. Truck driving and mechanical repair are typical male jobs. Again PFEM is very similar in the two countries in this decomposition. The Duncan index is a convenient summary of this information, and it confirms the similarity of occupational gender composition in the

${ }^{22}$ These definitions of male and female jobs are the more recently used in actual legislation's, in the Ontario Pay Equity Act., for example. 
two countries: it is equal to 59 percent in Canada and 58 percent in the United States. ${ }^{23}$

We also report average wages (in 1988 Canadian dollars) for all jobs and average wages by job type. Here we see some interesting Canada/U.S. differences. In the United States, women in female jobs are the lowest paid on average while women in mixed jobs are the highest paid. In Canada, it is the women in mixed jobs who are the lowest paid. None of the differences in average wages across job types would be statistically significant given the large standard deviations, but these descriptive statistics give a flavour of the results to come. The corresponding unadjusted female/male wage ratio is also reported in the last column of the table. The ratio averages 76 percent in Canada (for all jobs) and 72 percent in the United States; consistently higher in Canada, although the cross-country difference is not substantial. ${ }^{24}$ To account for the fact that more women than men work part-time, we compared that ratio to one computed weighting the data by hours of work. This correction actually raised the female/male wage ratio by about 1 percentage point in both countries. ${ }^{25}$

We also report the estimated coefficient $\hat{\gamma}$ from the regression, $\ln w_{i}=\delta+\gamma P F E M_{i}+$ $\epsilon_{i}$, estimated using the LMAS and CPS-ORG sample weights respectively. ${ }^{26}$ It is not surprising that for Canada the estimate of $\gamma$ for females is effectively 0 , as, on average, the lowest paid women are in mixed rather than female jobs. In contrast, for U.S. women the

${ }^{23}$ The Duncan index of segregation provides a measure of the concentration of women in certain occupations. Recall that this index can be interpreted as the proportion of the male or female employed population that would need to change occupations to achieve an even distribution.

${ }^{24}$ Macpherson and Hirsch (1995) report unadjusted female/male wage ratios for the U.S. of 0.692 for 1987 and 0.699 for 1988 . These ratios are higher then those typically reported for the earnings of full-time full-year workers (approximately 0.65 for Canada in 1988). Similarly, Drolet (1999) finds a female/male ratio of 0.803 using hourly wage rates and a ratio of 0.683 using the earnings of full-time full-year workers in 1997.

${ }^{25}$ Given the small effect of the hours weighting, we did not pursue that strategy in the regression analysis, but used it in the density estimation.

${ }^{26}$ As we report below, the estimates without control variables are the same with various estimation strategies. The standard errors are those of the proposed two-step strategy that used the sum of individual level weights by occupations as weights in the second step. 
implied elasticity at an average percentage female of 0.67 is $(0.67 \times-0.227)-0.152$. The two countries switch places in the comparison for males. It is now the American men that face the much smaller penalty.

The occupations "driving" the simple regression coefficients for Canadian women and men are illustrated in figures 1 and 2 respectively. We plot the regression line of average occupational log wages on the femaleness rate of the occupation. The relative sizes of the circles indicate the relative weights of the occupations. These pictures clearly show that the regression line is essentially flat for women, while it is negatively sloped for men. For women, a sizeable number of relatively highly paid nurses and kindergarten and elementary teachers would seem to compensate for an equal number of relatively low paid waitresses and cashiers. Among men, there is a sizeable proportion of the workforce employed as waiters and cashiers but not as many nurses and teachers.

In figure 3 we plot weighted kernel regressions of the relationship between wages and femaleness for both women and men. ${ }^{27}$ Both lines reveal some non-linearities, in particular a dip around the 55 percent femaleness rate; this is attributable to the sales clerk occupation, which is typically, paid the minimum wage. Moving above the 70 percent rate women's wages appear to rise, or at least not fall, while men's wages appear to decline. This figure also brings to light an interesting aspect of the gender wage differential: it is present at all levels of the femaleness rate, and is larger in male jobs. In a relative sense, women appear to be lower paid in very male jobs $(P F E M<0.1)$ than in very female jobs $($ PFEM $>0.9)$.

Differences in the wages of women and men may result from differences in individual characteristics, in particular in human capital variables. In table 2 we report the average

${ }^{27}$ Kernel regressions are easily understood with reference to moving averages. Around any femaleness rate, a moving average could be computed as the sum of average occupational wages times a rectangular weighing function of a given width. The corresponding kernel regression would be computed as the sum of average occupational wages times a Gaussian weighting function, called the kernel, of given bandwidth. Here, the bandwidth used is 0.05 . 
characteristics of the Canadian samples by gender. The table shows that on average working women are more educated than working men. Approximately the same proportion of women and men hold a university degree, while a higher proportion of women hold a post-secondary degree and a lower proportion are dropouts. On the other hand, there are other gender differences that work to the disadvantage of women. They have lower levels of tenure and work in smaller firms.

Another difference between working men and women is the proportion of workers covered by collective bargaining. In our samples, the union coverage rate for men is 8 points higher than for women. Doiron and Riddell (1994) argue that the gender wage gap would have increased by 7 percentage points between 1981 and 1988 if not for the reduction in the gender unionization gap which occurred over this period. ${ }^{28}$ An illustration of the potential impact of unionization on the effect of gender composition on women's wages is shown in figure 4 . We plot kernel density estimates, which can be understood as smoothed histograms, of wages by job type for both women and men. ${ }^{29}$ The union coverage rates among Canadian women in 1988 are 43 percent for female jobs, 26 percent for mixed jobs, and 35 percent for male jobs. As argued in DiNardo, Fortin and Lemieux (1996),

${ }^{28}$ Our rates, as well as those of Lemieux (1993) and Riddell (1993), are higher than those reported by Doiron and Riddell (1994) for 1988 LMAS (38 percent for males and 29 percent for females). Based on the LMAS, Riddell (1993) reports (p. 113) union coverage rates of 43.7 (40.5) percent for males and 35.2 (34.3) percent for females in 1986 (1990). Lemieux (1993) who uses the merged 1986-87 LMAS longitudinal files, reports (p. 76) union coverage rates of 45.8 percent for males and 36.4 percent for females. In addition to any effects of the differences in survey years, part of the difference appears to be due to our exclusion of full-time students. Adding these individuals back into our sample we obtain unionization rates of 43.2 percent for males and 35.4 percent for females. Additional differences with Doiron and Riddell may be due to our exclusion of workers unemployed in the week of interest (third week of November).

${ }^{29}$ We use a bandwidth of 0.07 and a Gaussian weight function. Each observation is weighted by the product of the sample weight and the usual hours of work per week. These "hours-weighted" estimates put more weight on workers who supply a large number of hours to the market. Also all densities presented here integrate to one and thus do not reflect the relative weights of the types of jobs. 
unionization leads to a more compressed wage structure. Correspondingly, the densities of women's wages in both female jobs and male jobs are much more compressed than the corresponding density in mixed jobs; these former densities in fact share the same mode. Figure 4 also shows that a large proportion of women working for the lowest wages are in mixed jobs. ${ }^{30}$ Finally, whatever the job type, the densities of women's wages lie to the left of the men's densities.

Differences in the occupational characteristics of the jobs in which women and men work have also been investigated as a potential explanation of the effect of gender composition on wages. Women may earn less because they work in occupations which require less skills and are thus less productive or valuable to the firm (Hodson and England 1986). Men may earn more because they work in riskier jobs (Leigh 1984), that carry compensating wage differentials. To investigate this possibility we examine the contribution of some important job characteristics from the Canadian Classification and Dictionary of Occupations (CCDO). The CCDO is a Canadian equivalent of the Dictionary of Occupations Titles (DOT) which has been used as a source of occupational characteristics in U.S. studies. The CCDO was first designed as a device for matching workers and jobs, and to provide a basis for a revision of occupational codes for the 1971 census; it has been periodically revised since then. ${ }^{31}$

As explained in more detail in section 5.1, we extract the following characteristics from the CCDO: general educational development (GED), specific vocational preparation (SVP), physical demands, and environmental conditions. Updated GED and SVP were

\footnotetext{
${ }^{30}$ This results hinges on whether the occupation "sales clerk" is a mixed or a female job; this may vary by province.

${ }^{31}$ Each of more than six thousand occupations is characterized in terms of 1) training times through general educational development (GED) and specific vocational preparation (SVP), 2) physical demands (8 possible requirements), 3) environmental conditions (7 types of physical surroundings), 4) worker functions as they relate to people, data and things at various levels, 5) eleven aptitude factors, 6) ten interest factors and 7) twelve temperament factors. See the appendix to the guide (Canada (1971-1973)) for more detail.
} 
available from the Strategic Policy Group at Human Resources Development Canada in machine-readable form. The other characteristics, however, had to be typed in from the various manuals and their updates. ${ }^{32}$ The job characteristics are available for the sevendigit occupation codes (more than 6,500 categories) and, in the absence of appropriate weights, have to be averaged over the four-digit categories. ${ }^{33}$ An analysis of the CCDO worker-traits performed by Hunter and Manley (1986) concluded that, while problems of reliability and validity might exist, it is possible to construct useful indicators using these data. Although any gender bias of the CCDO occupational characteristics has yet to be assessed, there are likely the same problems as with the DOT counterparts (see, e.g. Miller, Treiman, Cain and Ross (1980)).

\section{ECONOMETRIC FRAMEWORK}

\subsection{Cross-Section Strategies}

Drawing from the different perspectives of standard human capital theory and of personnel economics (or human resource management), we include both individual and job characteristics in our model of wages. The log wages of individual $i$ are specified as

$$
\ln w_{i}=X_{i} \beta+\alpha_{k} \cdot O C C_{k}+v_{i}
$$

where the $X_{i}$ are characteristics which vary by individual, $O C C_{k}$ are occupation dummies which take the value 1 if the individual is in occupation $k$ and 0 otherwise, and $v_{i}$ is an

${ }^{32}$ The original guide (Canada (1971-1973)) has been updated through six manuals: Canada (1977), Canada (1971, c1985a), Canada (1980), Canada (1971, c1985b), Canada (1978), Canada (1978). While Hunter and Manley (1986) have made a machine-readable version of 43 out of 52 CCDO worker-trait items available, their version relates to the 1971 SOC and does not include environmental conditions.

${ }^{33}$ Note that a similar procedure was used in Macpherson and Hirsch (1995). 
individual specific error term. The occupation wage effects, $\alpha_{k}$, capture the impact of the various characteristics of occupation $k$ on individual wages, conditional on the individual characteristics $X_{i}$. The interest here is one characteristic in particular: the percentage of employment in occupation $k$ that is female, denoted $P F E M_{k}$. Therefore, we focus on the equation

$$
\alpha_{k}=\lambda+\gamma P F E M_{k}+\eta_{k}
$$

where $\gamma$ is the parameter of interest and where $\eta_{k}$ captures the wage effects of occupation k's characteristics other than PFEM .

A common assumption in previous studies is that the residual occupation effects, $\eta_{k}$, are "random" (that is orthogonal to $P F E M_{k}$ ). In this case estimating equation (2) yields unbiased estimates of $\gamma$. To implement this "two-step" approach, we first estimate (1) by weighted least-squares (WLS), using LMAS supplied individual level weights. The resulting estimates of the occupation wage effects can be expressed as

$$
\widehat{\alpha}_{k}=\alpha_{k}+\epsilon_{k}
$$

where $\epsilon_{k}$ is the measurement error in the $\widehat{\alpha}_{k}$. Next we estimate the equation

$$
\widehat{\alpha}_{k}=\lambda+\gamma P F E M_{k}+\left(\epsilon_{k}+\eta_{k}\right)
$$

using the estimates of the occupation effects in equation (2) as dependent variable. The appropriate estimation strategy for (4) depends on which error component, $\epsilon_{k}$ or $\eta_{k}$, dominates the composite error term. On one hand, $\epsilon_{k}$ is likely to be heteroskedastic which would suggest a GLS strategy. The appropriate weights are proportional to an occupation's sample size or the variance of its fixed effect $\alpha_{k}$. On the other hand, there is no obvious reason why $\eta_{k}$ should not be homoskedastic. If it dominates, OLS is appropriate 
for the second stage and each occupation would be weighted equally. ${ }^{34}$

It is more common in the literature to obtain an estimate of $\gamma$ using a "one-step" method. Substituting (2) into (1) we obtain

$$
\ln w_{i}=\lambda+X_{i} \beta+\gamma P F E M_{k}+\left(\eta_{k}+v_{i}\right)
$$

Equation (5) yields unbiased estimates of $\gamma$ if $\eta_{k}$ is orthogonal to $P F E M_{k}$ and $X_{i} \cdot{ }^{35}$ The estimated standard errors would be biased, however, so the two-step procedure of (1) and (2) is preferred. This is because the composite error term is correlated across individuals within occupations due to $\eta_{k}$. This problem of using grouped data in an individual level regression has been discussed extensively by Moulton (1986).

Now, relax the assumption that the residual occupation effects, $\eta_{k}$, are uncorrelated with the individual characteristics and occupational femaleness rates. In the two-step procedure, any wage related occupational characteristics do not bias the estimate of $\beta$ because we include unrestricted occupation fixed effects in the first stage. The estimate of $\gamma$ from the second stage, however, is subject to a standard omitted variables bias. In the one-step procedure the estimates of both $\beta$ and $\gamma$ are biased. For the former parameter, it is occupation effects that are not linear in $P F E M_{k}$ and correlated with the $X_{i}$ that cause the problem.

Some previous studies report that one-step and two-step estimation strategies can lead

${ }^{34}$ This strategy thus takes jobs as unit of observation rather than individuals. For problems with this type of analysis, see Cheng, Orazem, Mattila and Greig (1997). Also, note any weaknesses of the occupation classification system will carry into the estimation. The occupation classification systems used in this study are male biased in that they classify blue collar workers at a more detailed level than white-collar workers. More precisely, there are 299 male occupations, 133 mixed occupations and 80 female occupations in our Canadian sample. American 3-digit occupation codes are vulnerable to similar criticism.

${ }^{35}$ Note that if $\eta_{k}$ is correlated with the $X_{i}$ (and therefore $\hat{\beta}$ is biased) the estimate of $\gamma$ will still be unbiased if $P F E M_{k}$ is orthogonal to $X_{i}$. 
to different results. ${ }^{36}$ It is useful, therefore, to consider the instances in which they estimate the same object. All else equal, the two procedures should lead to similar estimates under the assumption that $\eta_{k}$ is truly a random effect. If the orthorgonality condition does not hold, then each procedure leads to a biased estimate of $\gamma$. The bias should be the same, however, if $i$ ) there are no other control variables in the regression (i.e., no $X_{i}$ ), or $i i$ ) the $\beta$ in the first stage of the two-step procedure is the same as the $\beta$ in the one-step. As noted above, the estimate of $\beta$ from the two-step procedure is unbiased while the estimate of $\beta$ from the one-step is not. This simple difference is not sufficient, however, to cause the bias in the estimates of $\gamma$ to be different in the two procedures. The additional requirement is that the individual characteristics, $X_{i}$, be correlated with the femaleness rate, $P F E M_{k}$. If instead they are orthogonal, then the bias in the two procedures should be similar.

To make the argument more concrete it is useful to think about the possible components of the residual occupation effects, $\eta_{k}$. As noted above, one possibility is omitted job characteristics that may be the basis of compensating wage differentials. The evidence in Macpherson and Hirsch (1995) suggests there is a significant bias in estimates of the effect of gender composition on wages when these characteristics are omitted. Another candidate is the average characteristics of co-workers in an occupation. These can be motivated by human capital externalities (see, for example, Acemoglu and Angrist (2000) and Moretti $(1999)) \cdot{ }^{37}$

This latter example is interesting because it is a type of omitted variable that would lead the one-step and two-step estimates of $\gamma$ to differ. Observable components of these human capital externalities are just the average $X_{i}$ by occupation, denoted $\bar{X}_{k}$. Suppose the bias in $\gamma$ is due to the correlation of $P F E M_{k}$ with the omitted variable $\bar{X}_{k}$. Since $\bar{X}_{k}$

${ }^{36}$ For example, Macpherson and Hirsch (1995) (p.450) report that the gender composition coefficient for males (using their expanded specification) is -0.0986 from a one-step procedure, and -0.1305 from a two step procedure.

${ }^{37}$ Individuals' wages increasing in the average education in their occupation is an example of such an externality effect. 
is correlated with $X_{i}$ by construction, $P F E M_{k}$ is also correlated with $X_{i}$. In this case the standard omitted variable bias in the one-step estimate of $\gamma$ is compounded by the bias in the estimate of $\beta$. In the two-step procedure the estimate of $\beta$ is umbiased, and there is only the standard omitted variables bias in $\hat{\gamma}$.

Omitted variables such as job characteristics and average individual characteristics by occupation are at least partially observable here. Therefore, we can condition on them explicitly in an attempt to attenuate the bias and reconcile any differences between the one-step and two-step approaches. To formalize, specify $\eta_{k}$ as

$$
\eta_{k}=\bar{X}_{k} \delta+C_{k} \kappa+\psi_{k}
$$

where $C_{k}$ are the CCDO occupational characteristics, and $\psi_{k}$ are all other unobserved wage effects of occupation $k$ characteristics. Substituting into (3) we obtain

$$
\widehat{\alpha}_{k}=\lambda+\gamma P F E M_{k}+\bar{X}_{k} \delta+C_{k} \kappa+\left(\psi_{k}+\epsilon_{k}\right)
$$

for the two-step approach. Substituting into (5) we obtain

$$
\ln w_{i}=\lambda+X_{i} \beta+\gamma P F E M_{k}+\bar{X}_{k} \delta+C_{k} \kappa+\left(\psi_{k}+v_{i}\right)
$$

for the one-step. Note that in either case (equation (7) or equation (8)) the estimate of $\gamma$ remains potentially biased if $\psi_{k}$ is not orthogonal to the included regressors. ${ }^{38}$

We investigate these hypotheses offering estimates of $\gamma$ from a variety of procedures. First, to link with the extensive literature in this area we present simple one-step, WLS estimates of (5). Note that this approach is potentially inappropriate in any scenario, as either or both of the estimates of $\gamma$ and the standard errors are biased.

${ }^{38}$ Also note that even if $\eta_{k}$ is orthogonal, there are potential efficiency gains from estimating (7) instead of (2). 
Second, we consider a variety of two-step estimators that are appropriate under the assumption that $P F E M_{k}$ is uncorrelated with $\eta_{k}$. Following the discussion of equation (4) we present results from three feasible GLS estimators of the second stage. The first, denoted GLS0, is OLS estimation. In the second, GLS1, we use the WLS estimates of the sampling variances of $\widehat{\alpha}_{k}$ from the first stage regressions as weights. ${ }^{39}$ Finally in the third, GLS2, the sum of the LMAS sample weights (by occupation) are used as weights.

We also attempt to reconcile any differences between the one-step and two step estimates of $\gamma$, comparing one-step WLS estimates of (8) with two-step estimates of equation (7).

\subsection{Panel Strategies}

Another issue in the estimation of $\gamma$ is the presence of unobserved individual effects that are correlated with PFEM. A way to address these sort of biases is to use longitudinal data. A longitudinal analysis of wage changes allows us to identify a person-specific component, $u_{i}$, that does not change over time, in the error term of equation (1)

$$
\ln w_{i t}=X_{i t} \beta+\alpha_{k} \cdot O C C_{k i t}+u_{i}+\varepsilon_{i t}
$$

where $t$ denotes the time period. Using the time operator $\Delta$ to denote changes over time, we write the wage changes as $\Delta \ln w_{i}=\ln w_{i t+1}-\ln w_{i t}$, and the occupational changes as $\triangle O C C_{k i}=O C C_{k i t+1}-O C C_{k i t}$, among other changing variables. ${ }^{40}$ This framework makes

${ }^{39}$ Since the first stage regressions are estimated by weighted least-squares using the LMAS sample weights, following Wooldridge (1998) it might be preferable to use White estimates of the sampling variances of the $\widehat{\alpha}_{k}$ as weights in GLS1. Note, however, that many of the occupation cell sizes are very small so the finite sample bias of the White estimates could be quite severe. We have experimented with this procedure and in practice found that it yields results very similar to the GLS0 estimates reported in table 3 (i.e., it weights the different occupations fairly evenly).

${ }^{40}$ Note that the $\triangle O C C_{k i}$ are different from zero only for occupation switchers with a value of -1 for the old occupation and 1 for the new occupation. 
clear that identification rests on occupation switchers. ${ }^{41}$ The log wage changes equation is written as

$$
\Delta \ln w_{i}=\Delta X_{i} \beta+\alpha_{k} \cdot \Delta O C C_{k i}+\Delta \varepsilon_{i} .
$$

The person-specific component that is potentially correlated with unobserved ability and tastes, and with the femaleness of occupation, differences out. In theory, the estimates of $\alpha_{k}$ from equation (9) capture the effect of occupational changes on changes in wages and can be regressed on $\triangle P F E M$ to obtain the effect of changes in femaleness rates on wage changes. This strategy is only feasible, however, when there is a larger number of occupation switchers than occupations. ${ }^{42}$ In application, since our number of occupation switchers is small we revert to one-stage estimation using the equation:

$$
\Delta \ln w_{i}=\Delta X_{i} \beta+\gamma \Delta P F E M_{k}+\Delta e_{i}
$$

The standard errors on the corresponding levels equations will help us benchmark correct standards errors for the wage changes equation.

\section{RESUlTS}

\subsection{Cross-Section Estimates of the PFEM Wage Penalty}

In table 3 we present various one-step and two step estimates of the relationship between wages and the femaleness of occupations in Canada. In the first row of each panel are the

${ }^{41}$ Because our measure of PFEM is from the census, it does not vary between 1988 and 1989 for individuals who do not change occupations. $\triangle P F E M$ is different from zero only for occupation switchers.

${ }^{42}$ When the number of occupation switchers is not much larger than the number of occupations, it is very likely to find only one observation by occupation left (dummy $=-1$ ) and occupation entered (dummy=1). In that case, the corresponding occupation dummies are collinear and the matrix of occupational changes is singular. 
estimates of equations (4) and (5) conditioning on "human capital" variables, a quartic in age and six education classes, for females and males respectively. ${ }^{43}$ Under the common assumption that any residual occupation effects are random, the estimates from the various procedures should be similar, although the standard errors for the WLS estimates are potentially biased.

For females there is a fairly wide range of estimates across the different procedures in 1987. Both the WLS and GLS2 estimates suggest a very modest wage penalty in female jobs. The latter estimate is statistically insignificant, while the significance of the former is hard to evaluate as the standard error estimate is biased. Both the GLS0 and GLS1 procedures suggest a larger penalty. Relative to WLS and GLS2, these procedures weight the different occupations more equally. The disagreement between the different procedures is much smaller in the 1988 data. Here the penalty is consistently small and mostly statistically insignificant. The estimates for males in either year are uniformly much larger than the counterparts for females. For example, given an average PFEM of 0.25 , the two-stage estimates for males, which average roughly -0.23 across the two years, imply an elasticity of $-0.058(0.25 \times-0.23)$. There is little consistent pattern to the differences in the estimates across the procedures, except that the one-step tends to be the largest in absolute value.

In the second row of each panel we add explanatory variables in an attempt to replicate the conditions in which a pay equity policy might be implemented. Their target is the relationship between wages and PFEM, net of differences in allowable productivity related characteristics. Therefore, we attempt to control for systematic variation in wages across firms and with job/individual characteristics which are likely to be tolerated in the representative legislation. Johnson and Solon (1986) show that this exercise highlights

${ }^{43}$ The returns to these human capital variables are reported in Baker and Fortin (2000) for 1988. They show dramatic differences between males and females justifying the separate estimation by gender that is common in the literature. 
the limitations of pay equity policies. In particular, much of the correlation of wages and PFEM is across industries and firms, and thus outside the purview of most legislation. The additional explanatory variables in these regressions are province effects, 11 industry effects and dummy variables for metropolitan area, employment in the federal, provincial or local governments, union coverage and part-time status.

The main difference in inference for females is that the one-step estimates in either year are larger. Most of the two-step estimates continue to indicate a relatively modest penalty. For males we obtain much smaller estimates of $\gamma$ conditioning on these additional variables, although in each year the penalty is still larger than the estimates for females.

In the third row, we include demographic variables, some of which are unlikely to be considered legitimate bases of wage variation in pay equity legislation. These include tenure, firm size, the numbers of preschool and older children respectively (up to 3) (for 1988) and dummy variables for marital status and visible minority status. For females there are very small effects on the inference. With the exception of the GLS0 estimate for 1987 , the two-step procedures continue to produce modest estimates which we cannot reject are equal to zero. The one-step procedure still indicates a much larger penalty. Similarly for males the additional control variables have little effect on the point estimates. In this case, however, we observe much less disagreement among the various procedures.

As discussed in Section 4, the differences between the one-step and two-step estimates suggest the assumption that the residual occupation effects, $\eta_{k}$, are random may be inappropriate. Of particular note are the disagreements between the WLS and GLS2 estimates for females in either year. They are important because the two estimates lead to very different conclusions regarding the wage penalty women face in female jobs. Furthermore, the weighting is comparable in these two procedures, so an argument based on parameter heterogeneity across occupations is unlikely to reconcile the disagreement. ${ }^{44}$

\footnotetext{
${ }^{44}$ Note that if there is parameter heterogeneity across occupations, then the different two-
} 
To construct a reconciliation, it is important to first note that when there are no additional control variables, the estimates from the WLS, GLS1 and GLS2 procedures are the same, and equal to the results reported in table 1. In line with the discussion in Section 4, the divergence emerges with the addition of the control variables $X_{i} \cdot{ }^{45}$ Following the argument there, adding the observable components of omitted occupational characteristics should help bring the estimates into line. We begin in the fourth row of each panel adding the $\bar{X}_{k}$ as additional regressors to the one-step and second stage of the two-step procedures, using the "Individual Characteristics" specification. The effect is remarkable. First, for females in either year the estimates from the different procedures are very similar. Second, the match between the WLS and GLS2 estimates (two estimators with comparable weighting schemes) is almost exact. Third, there is also greater resemblance among the different estimates for males, with the greatest again between the WLS and GLS2 results. ${ }^{46}$

Although a reconciliation of the different estimates has been achieved, it would be premature to draw any conclusions about the wage penalty in female jobs. We have yet to consider the effect of omitted job characteristics, $C_{k}$, that potentially bias the estimates of $\gamma$ in table 3. Recall that these characteristics have a substantial effect on estimates from American data. In the first panel of table 4 we add the CCDO job characteristics to the "Individuals Characteristics" specification of table 3. To reduce the dimension of the exercise we focus on the data from 1988. We also restrict our attention to the WLS and GLS2 strategies.

step procedures potentially estimate different objects. For example, GLS0 (equally weighted) estimates the wage penalty in the average occupation, while GLS2 estimates the penalty faced by the average individual.

${ }^{45}$ Note that when there are no additional control variables the weighting in GLS1 and GLS2 is similar. This follows from the fact that in this case the $\left(X^{\prime} X\right)^{-1}$ matrix for calculating the variances of the estimated occupation effects in the first stage is diagonal, with elements equal to one over the sum of the individual level weights by occupation.

${ }^{46}$ Regressions not reported reveal that adding the $\bar{X}_{k}$ as an additional regressor yields almost complete agreement between the WLS and GLS2 estimates in the "Human Capital" and "Sectoral Controls" specifications. 
In the first row we add controls for the CCDO training time requirements: general educational development (GED) and specific vocational preparation (SVP), measured in years. The general educational development corresponds to the duration of formal schooling required to attain average, satisfactory performance in the occupation. The specific vocation preparation is an estimate of the time required to learn the techniques and skills needed for satisfactory performance. First note that like the $\bar{X}_{k}$, the addition of these regressors brings greater agreement between the WLS and GLS2 estimates, although not to the same degree. Second, the resulting estimates of the wage penalty are much smaller for females, and marginally larger (GLS2) or unaffected (WLS) for males. Macpherson and Hirsch (1995) found these sorts of controls decreased the estimated relationship between wages and gender composition for both males and females. ${ }^{47}$ In specification 6 , we add a control for hazards defined in terms of the CCDO sixth category of environmental conditions as situations in which the individual is exposed to the definite risk of bodily injury. This control decreases the magnitude of the PFEM coefficients for males. The estimates for females are now positive, but in either rows 5 and 6 the results are not statistically significant.

In the seventh specification, we use the following controls for strength and physical demands: sedentary work-medium work, heavy work, bending, visual skills and motor coordination. $^{48}$ Finally, in specification 8 we add controls for outside and inside work, corresponding to the CCDO work location variable (EC-1). Overall, these additional controls lead to an estimate of $\gamma$ for females which is essentially 0 . For males, the additional controls

${ }^{47}$ We note that the effect of adding these characteristics is similar in the 1987 data. For example, the estimates for specification 5 in table 4 are -0.025 (0.013) with WLS and -0.017 (0.025) with GLS2 for women, and -0.104 (0.013) with WLS and -0.132 (0.022) with GLS2) for men.

${ }^{48}$ Following a multifactorial analysis of the original CCDO codes we constructed the following variables. Using the CCDO codes, in the physical activities (PA) category, sedentary workmedium work corresponds to PA-1: S,S-L,S-M; heavy work to PA-1: $\mathrm{H}$ and VH; bending to PA-3; visual skills to PA-7; and motor coordination to the sum of PA-2-4-8. 
lead to modest reductions in the estimated relationship between wages and occupational gender composition.

At this point it is interesting to compare the results to estimates for the United States from a similar specification. In their "expanded" specification that includes a variety of job characteristics and is therefore most comparable to our specification 8, Macpherson and Hirsch (1995) report that the estimated penalty for American females in 1988 is -0.119 , and for males -0.0989 . Therefore, the evidence here is of a dramatically smaller penalty for Canadian females and a roughly comparable penalty for Canadian males.

In the second panel of table 4 we add the occupational averages of the individual characteristics, $\bar{X}_{k}$, as additional regressors. The incremental contribution for females is small. The WLS and GLS2 estimates now match almost exactly, but are little different from the estimates in the top panel. For males the GLS2 estimates are now smaller while the WLS estimates are essentially unchanged. Also, the two estimates are now in near exact agreement.

The inference, therefore, is that at the aggregate level women in Canada face almost no wage penalty in female work. Certainly the penalty is much smaller than that faced by women in the United States. For males the penalty is much larger, significantly different from zero and comparable to that faced by American males. Estimates for either sex are sensitive to model specification. The penalty for females observed in leaner specifications disappears once we control for the job characteristics of female jobs. That said, even if these characteristics are excluded, the penalty for women remains smaller than its U.S. counterpart. 49

It is also important to note some limitations of our results. First, the estimates of $\gamma$ in table 4 are potentially biased by omitted occupational characteristics that are correlated

\footnotetext{
${ }^{49}$ Using a specification comparable to our "Individual Characteristics" specification, Macpherson and Hirsch (1995) report an estimated penalty for females of -0.1683 , and for males of -0.1956 in 1988.
} 
with the included regressors. Second, our reconciliation of the estimates from the various estimation procedures relies on the addition of the $\bar{X}_{k}$ to the regression equations. Depending on the model assumed to underly individual occupational choices, the estimated parameters on these averages may be biased. ${ }^{50}$ Since these averages are, in turn, correlated with $P F E M_{k}$, this may further bias the estimates of $\gamma$.

\subsection{Heterogeneity in the Effect of Gender Composition on Wages}

An objection to the analysis thus far is that we are failing to capture any heterogeneity in the effects of gender composition on wages across groups; for example, union/nonunion or full-time/part-time differences. Furthermore, it's possible that the aggregate estimates of $\gamma$ we have presented hide these sorts of differences; for example, if we focus on full-time workers we may recover the "expected" larger negative estimates.

In table 5 we present estimates of $\gamma$ for males and females in 1988 by different groupings to investigate this possibility. We present estimates from three specifications to provide a full spectrum of results. The first column has no additional control variables, the second column corresponds to the "Sectoral Controls" specification of table 3 and the third column is the "Individual Characteristics" specification with the addition of the CCDO's GED and SVP requirements and the occupational averages of the individual characteristics, the $\bar{X}_{k}$ (i.e., corresponding to specification 9 of table 4). We use the GLS2 two-step procedure and the data for 1988 .

The first panel contains the results by age. In the "Sectoral Controls" specification the penalty is modestly larger for women of prime working age. Once the job characteristics are added, however, the penalty appears to be fairly uniform across age groups. For men there is evidence that the penalty faced by young men is larger regardless of which specification

${ }^{50}$ Acemoglu and Angrist (2000) and Moretti (1999) provide a discussion of the biases in estimating human capital externalities. 
we use.

The second panel contains the results by education. In the first two specifications, the penalty for females follows a $\mathrm{U}$ shaped pattern, and is notably severe for those with a university degree. Once the job characteristics are added, however, the estimates of $\gamma$ become positive for most groups, although statistically insignificant. One explanation of the dramatic change in the estimate for university graduates in the third specification would be that women in female jobs are extremely overqualified for their positions. Interestingly a similar change in inference is observed for male university graduates in the third specification. Also, the penalty appears to decline monitonically with education for males.

In the third panel we investigate differences by union status. For females, there are strong union/non-union differences except in the third specification. For males union workers face a much smaller penalty than their non-union counterparts, regardless of the conditioning variables.

In the fourth panel we present estimates by full-time status. Here again, specification plays a role in the results. For females, it is initially full-time workers who face the larger penalty, but conditional on the educational requirements of the jobs it is the part-time workers who face the larger penalty. For males, at least qualitatively the story is again more consistent, as part-time workers face the larger penalties.

In the fifth panel, we investigate the potential impact of administrative pay systems that inspired the job evaluation schemes of comparable worth procedures, and are more prevalent in larger firms. ${ }^{51}$ We split the data by establishment size, identifying those with less than 100 employees and those with at least 100 employees. The point estimates for larger establishments are generally much smaller than those for smaller establishments, but it is only for males that the change has any meaning. For women, none of the estimates are statistically significant.

${ }^{51}$ Gibbs and Hendricks (1997) reports that 50\% of large U.S. establishments use such administrative pay systems. 
Finally, in the last panel we distinguish between the public and private sectors. Recall that in the late 1980 s pay equity legislation was in effect or forthcoming in the broader public sector of some provinces. While U.S. datasets typically include a variable called "class of worker" that identifies public and private sector workers, a similar variable is not available in our Canadian datasets. ${ }^{52}$ For example, we have no way of knowing whether a teacher works for a public or a private school. We therefore must use industrial sector of employment (see table 2) as a proxy, focusing on workers in public administration, medical, welfare and educational services and all other sectors. ${ }^{53}$

The results again display important differences across specifications. The first two specifications reveal a larger and statistically significant penalty for women in female jobs in Public Administration. Once the occupational controls are added, however, the estimate is very close to zero. In what we call the "public goods" sectors, medical, welfare and educational services, the penalty to female jobs clearly vanishes even in the leaner specifications. These estimates lend further support to the findings in Baker and Fortin (1999b). In that paper we argue differences in the relative positions of occupations, in particular of workers in "public good" sectors, account for an important part of Canada/U.S. differences in the effect of gender composition on female wages. Ranking average female occupational wages in the overall (men and women combined) wage distribution of each country, and plotting the country specific ranks of different jobs against each other, reveals that many "public goods" sector jobs, such as secondary teachers and nursing assistants, rank higher in Canada. ${ }^{54}$

\footnotetext{
${ }^{52}$ The variable used in Riddell (1993) for 1986 jobs has not been coded in our labour force surveys.

${ }^{53}$ The precise three-digit 1980 Standard Industrial Codes are: $811-817,822,823,825-827,832,835-$ 837,841 for public administration, and $851-855,859,861-869,981$ for medical, welfare and educational services.

${ }^{54}$ Private sector jobs, such as sales managers, rank higher in the United States. See also Baker and Fortin (2000) for a detailed analysis.
} 
One reading of table 5 is that there is little heterogeneity in the estimated penalty for females once we condition on occupational characteristics, especially educational requirements. In almost every split of the data we obtain estimates that are very small and not statistically significant. In contrast, for males there is heterogeneity and younger males, the less educated, the non-union, the part time and those in small firms face the larger penalty.

If the leaner specifications are preferred, then it would appear there is heterogeneity in the estimates for both males and females, and some of the estimates are quite large. Furthermore, even larger estimates are obtained if we combine the splits of the data. For example, if we restrict our attention to the sub-sample of full-time non-unionized women (47 percent of working women), we obtain estimates of around -0.24 (with standard errors around 0.06 ) in the first two specifications. ${ }^{55}$

It is interesting to note, however, that in our 1988 sample, 26 percent of full-time nonunionized women are employed in administrative and managerial occupations, which are mixed or male jobs. In Baker and Fortin (1999b) we demonstrate that the relatively higher pay of "mixed" jobs, in particular managerial jobs in the United States, helps account for the larger negative effect of gender composition on women's wages at the aggregate level in that country. In fact, when we exclude women employed in mixed occupations, who nominally are not covered by pay equity legislation, from the analysis, the wage penalty to female jobs in the U.S. vanishes. We observe a similar effect here for full-time nonunionized females. Deleting women in mixed jobs from the sample, we obtain statistically insignificant estimates of $\gamma$ ranging from -0.044 to -0.077 (with standard errors around 0.17 ) with the first two specifications. Therefore, occupational segregation between male and female jobs as delineated by comparable worth legislation does not appear to be "driving"

${ }^{55}$ In the third specification, the estimate for the full-time non-unionized women falls to -0.035 (0.042). As with the estimates for other groups of women it is small and statistically insignificant. 
the wage penalties for full-time non-unionized women in female jobs. ${ }^{56}$

A similar story can account for some of the large estimated penalties for females in other splits of the data. For example, the first two specifications suggest a large penalty to female work in public administration. Here again, workers in mixed managerial occupations play an important role. $^{57}$ If we remove women employed in mixed occupations from the sample, the estimates of $\gamma$ from the first two specifications fall by 50 percent, ranging from -0.111 to -0.116 (standard errors around 0.05 ) and are smaller than comparable estimates from the "other sectors", which range from -0.237 to -0.126 (standard errors around 0.05 ).

The estimates in table 5, therefore, do reveal some heterogeneity in the estimates across different groups of women and men, and across econometric specifications. Consistent with our aggregate inference, in most decompositions the penalty for males is larger than for females. For women, in a specification which includes occupational characteristics, the penalty is never statistically significant. In leaner specifications, we find estimates of the effect of gender composition on female wages, comparable to the aggregate penalty in the United States among the university educated, among non-unionized full-time women, and among women in the public administration sector. In the latter two cases, an important part of the penalty is attributable to the relative importance and the relatively higher pay of mixed occupations within these groups. ${ }^{58}$ More generally, the penalties for females are sensitive to the inclusion of occupational characteristics, while the estimates for males are more robust to the choice of specification.

\footnotetext{
${ }^{56}$ Note that comparable worth legislation ignores mixed jobs.

${ }^{57}$ Nineteen percent of women in public administration are employed in administrative and managerial occupations.

${ }^{58}$ When we remove women employed in mixed occupations among the university educated, the penalty remains high ranging from -0.314 to -0.334 (with standard errors around 0.11 ) in the first two specifications.
} 


\subsection{Longitudinal Analysis of Gender Composition and Wages}

To create the 1988-1990 LMAS longitudinal survey, the respondents to the 1988 survey were re-contacted to obtain retrospective information about their labour market activities in 1989 and $1990 .^{59}$ To mimic a two-points in time survey we retain individuals who were working and were not full-time students in the third week of November in both 1988 and 1989. Because the LMAS records the jobs individuals hold, we are able to identify job changers; they constitute approximately 12 percent of the longitudinal sample. Among the job changers, those whose occupation codes changed constitute our sample

of occupation switchers; they constitute approximately 8.5 percent of the longitudinal sample. In comparison to Macpherson and Hirsch (1995) in which occupation switchers are identified using changes in occupation codes, our sample of occupation switchers should be less prone to mis-measurement of occupational changes. ${ }^{60}$

The rationale for using panel data to examine the effect of gender composition on wages is to purge any bias from an unobserved individual specific component which is correlated with PFEM. An oft cited example is that women with higher levels of unmeasured skills may sort into male and mixed jobs (e.g. women with high leadership abilities are more likely to become managers than secretaries). ${ }^{61}$

\footnotetext{
${ }^{59}$ For example, we have information on the starting and stopping weeks of each job held by individuals. We use the total hours worked at each job in each of the two years to identify major jobs in the case of multiple job holders. Individuals who moved out of Canada, were found to have moved into an institutional setting or who passed away were considered to be out-of-scope. The LMAS longitudinal file consists of records for individuals responding in all the years covered by the survey.

${ }^{60}$ For example, we can check that occupation switchers also experienced a job change. Macpherson and Hirsch's (1995) occupation switchers are also restricted to the sample of successful matches across annual March supplements of the CPS.

${ }^{61}$ Among our job changers, we see a number of women moving from occupation 4111 (secretaries) to 1149 (managerial occupations). In our sample of initial jobs, $1.5 \%$ are in occupation 1149 and $8.0 \%$ in occupation 4111 while in our sample of subsequent jobs, the percentages are $2.4 \%$ and $6.0 \%$, respectively.
} 
Note that in application only individuals who switch occupations can be used to identify the parameter on PFEM. This is because our estimates of PFEM are taken from 1991 census data and therefore they do not vary across years for individuals who remain in the same 4-digit occupation. The "representativeness" of occupation switchers is therefore important to consider when interpreting the following results.

In table 6 we present the estimates from both the 1989 levels and the panel changes of wages, for both occupation switchers and for the whole sample. For the levels we present both GLS2 and WLS (one-step) estimates. The latter are, strictly speaking, more comparable to the one-step panel estimates.

For females, the results from the levels reveal that the occupation switchers are different than the average sample member. The estimated effect of gender composition is much larger for this group and statistically significant. That said, the panel estimates are much smaller and a remarkable match for the estimates in table 3 . Any penalty to female work is modest relative to estimates from the United States, and statistically insignificant. This is true whether the sample is restricted to the occupation switchers (top panel) or extended to the sample of all workers to provide additional control for secular wage changes (bottom panel). For men, the evidence of differences between the occupation switchers and the entire sample of workers is not as clear cut. Also, in this case the panel estimates are larger than the estimates from table 3, but not much different from the level estimates for the switchers. Overall, this analysis is limited by the evidence that occupation switchers do not appear to be representative of the sample. We do not, however, find the clear cut differences between level and panel estimates reported for the United States by Macpherson and Hirsch (1995). They find consistently smaller estimates of the wage penalty using panel, rather than levels, estimators. 


\subsection{A Comparison to the Results of Other Canadian Studies}

How do these results compare to those of other Canadian studies? As noted above, the Canadian literature is very small. Baker et al. (1993) obtain an estimate of $\gamma$ for females of 0.055 (0.034) in 1985 using the gender composition of 2-digit occupations. This is not inconsistent with our small estimates for females, as they also show that the estimated parameter on PFEM is more positive (less negative) as you aggregate occupations, and our results are based on the gender composition of 4-digit occupations.

Reilly and Wirjanto (1999) report much larger estimates of a penalty to "female work", defined at the establishment level rather than the occupational level, for the Maritime provinces in 1979: $-0.293(0.110)$ for females and $-0.223(0.083)$ for males. In addition to the difference in year, differences in sample and the definition of PFEM complicate direct comparison of these results with the estimates here. First, Reilly and Wirjanto's results are for three provinces. Second, they restrict their sample to full time workers, and their sample does not include the governmental and finance sectors. Third, they use a smaller (and different) set of control variables. Finally, and perhaps most importantly, Reilly and Wirjanto measure PFEM at the establishment, rather than the occupational level. Conditional on some broad occupational controls, their definition of a female job is work in a firm that has a high proportion of females. Our definition of a female job is an occupation that has a high proportion of females, even if the work is completed at a mostly male firm. Of course, the two definitions are related as many women who work in female occupations may also work in female firms. Alternatively, the Reilly and Wirjanto study speaks to the debate surrounding policies such as affirmative action and employment equity, while the analysis here is related to the debate over comparable worth/pay equity programs. 


\section{Gender Gap and Gender Composition}

Pay equity/comparable worth legislation has been enacted in some jurisdictions in an attempt to reduce the gender gap, understood to be mainly caused by occupational segregation. The specific target and the evaluation of these policies thus is typically debated against the background of the gender wage gap. There is some interest, therefore, in discovering how PFEM contributes to the difference in wages between males and females.

From our first stage regressions we have

$$
\overline{\ln w^{j}}=\hat{\beta}^{j} \overline{X^{j}}+\widehat{\alpha}_{k}^{j} \cdot \overline{O C C_{k}^{j}}
$$

where we now add superscripts to distinguish estimates for males and females ( $j=M, F)$ and the overbar denotes the relevant mean. This implies

$$
\left(\overline{\ln w^{M}}-\overline{\ln w^{F}}\right)=\left(\hat{\beta}^{M} \overline{X^{M}}-\hat{\beta}^{F} \overline{X^{F}}\right)+\left(\hat{\alpha}_{k}^{M} \cdot \overline{O C C_{k}^{M}}-\hat{\alpha}_{k}^{F} \cdot \overline{O C C_{k}^{F}}\right) .
$$

The second term on the right hand side of (13) is just that part of the log wage differential that is accounted for by differences in the occupation effects and the distribution of individuals across occupations. Similarly, from the second stage regressions we have

$$
\overline{\widehat{\alpha}^{j}}=\hat{\lambda}^{j}+\hat{\gamma}^{j} \cdot \overline{P F E M^{j}} .
$$

A standard Oaxaca decomposition of the second stage equations for males and females yields

$$
\left(\overline{\hat{\alpha}^{M}}-\overline{\hat{\alpha}^{F}}\right)=\left(\hat{\lambda}^{M}-\hat{\lambda}^{F}\right)+\hat{\gamma}^{M}\left(\overline{P F E M^{M}}-\overline{P F E M^{F}}\right)+\overline{P F E M^{F}}\left(\hat{\gamma}^{M}-\hat{\gamma}^{F}\right)
$$

Equations (13) and (15) are related by noting that $\widehat{\alpha}_{k}^{j} \cdot \overline{O C C_{k}^{j}}$ in (13) is implicitly the sum 
$\sum_{l=1}^{K} \widehat{\alpha}_{l}^{j} \cdot \overline{O C C_{l}^{j}}$, and that $\overline{\widehat{\alpha}^{j}}=\sum_{l=1}^{K} \widehat{\alpha}_{l}^{j} \cdot \overline{O C C_{l}^{j}}$ when we use GLS2 to estimate the second stage regression. ${ }^{62}$ Therefore, under the GLS2 weighting scheme equation (15) provides a decomposition of that part of the log wage gap that is accounted by male/female differences in both occupational employment and occupational returns. Note also from (14) that

$$
\left(\widehat{\gamma}^{M} \cdot \overline{P F E M^{M}}-\widehat{\gamma}^{F} \cdot \overline{P F E M^{F}}\right)
$$

is just that part of the wage gap due to differences in both the average femaleness of employment and the associated penalties.

One way of viewing (16) is as an (ceteris paribus) estimate of the potential effect of policies aimed at eliminating the correlation of wages with PFEM on the log wage differential (i.e. if $\gamma^{M}=\gamma^{F}=0$ ). ${ }^{63}$ Estimates of (16) are easily constructed for 1988 using average PFEM from table 1 and the GLS2 estimates of $\gamma^{j}$ for this year from table 3. The estimates range from -0.04 to $0.02 .^{64}$ The results using estimates from table 4 are similarly small. Therefore, the aggregate effect of $\gamma$ and PFEM is very modest. While females are penalized by a much larger average value of PFEM, they gain from having much smaller estimates of $\gamma$. Since the log wage gap in Canada was 0.27 in 1988, these results suggest that all else equal, eliminating the effects of gender composition on wages would have limited effect on the log wage differential.

${ }^{62}$ Note that $O C C_{k}^{j}$ is a $0 / 1$ variable.

${ }^{63}$ Note we are ignoring any obstacles pay equity policies might face in achieving this goal. See, for example, Johnson and Solon (1986).

${ }^{64}$ The estimates are $-0.042,0.019,0.014$ and 0.005 for specifications one through four respectively. 


\section{Discussion and Conclusions}

Our analysis of the effect of gender composition on wages in Canada has uncovered some surprising differences from the evidence for other countries. Estimates of the relationship between wages and gender composition can be sensitive to the choice of estimation strategy and the inclusion of any additional control variables. Although there is some heterogeneity across subgroups, most estimates for women are quite modest and typically statistically insignificant. The estimates for men, however, are uniformly negative, revealing a more substantial penalty for work in female jobs.

These results contrast with estimates from the large U.S. literature in this area. For example, Macpherson and Hirsch (1995) report that males and females in the United States faced quite similar, negative effects of gender composition on wages in 1987 and 1988. While our estimates for males are roughly comparable to these results, the estimates for females are quite different. ${ }^{65}$ An important finding in the analysis of Macpherson and Hirsch is substantial reductions in the wage penalty to female jobs when they control for detailed job characteristics, suggesting the lower wages in female jobs are related to (typically) unobserved job attributes or requirements. For Canadian women, the addition of these characteristics would appear to have a more dramatic effect driving the estimates to zero. Macpherson and Hirsch also report substantial reductions in the wage penalty when they attempt to control for unobserved tastes and ability using panel data. In contrast, our longitudinal and cross-sectional analyses offer mostly the same conclusions.

Analysis at finer levels of aggregation reveals some heterogeneity in the penalty across groups, but the size of these penalties is sensitive to the choice of control variables. In leaner specifications, females who are university graduates face significant penalties to working in

\footnotetext{
${ }^{65}$ As noted above, in Baker and Fortin (1999b) we argue that a large part of the Canada/U.S. difference for females is accounted for by cross-country differences in unionization and differences in the wage premiums to certain "public goods" sector jobs.
} 
female jobs relative to co-workers in male jobs. Larger negative penalties are also found for females in full-time non-unionized work and in public administration. An interesting property of the latter two estimates is that they depend on the relative wages in "mixed" jobs, that would be nominally untreated by pay equity legislation. When a more complete set of occupational controls is included, all penalties for women in female jobs disappear. The corresponding penalties for males are more uniform across the different econometric specifications and decompositions of the data.

Our evidence is from a period (1987-1988) when the labour market was mostly untouched by the effects of pay equity legislation. Since this time, pay equity programmes have been introduced to the public sectors of most provinces, the private sector of Ontario, and more recently to the private sector of Quebec. The results of this study provide some perspective on the "target" for these initiatives, as well as any further extensions of comparable worth in other provinces.

The aggregate relationship of wages with gender composition is typically a rallying point for advocates of pay equity legislation. Our results suggest that for women this aggregate relationship is very small and perhaps zero. Correspondingly, a simulation of the contribution of occupational gender segregation to the aggregate gender wage differential is quite modest. This raises the question whether a universal pay equity program would provide widespread benefits to women.

There are at least two important caveats to these conclusions. First, our results do not preclude the existence of low paid female jobs, such as waitresses and cashiers. However, there are some women who are equally low paid in mixed and males jobs: sales clerks and food preparation workers (mixed), and material handlers (male). More importantly, some women hold female jobs that are relatively highly paid, such as nurses and teachers. As a result, the gender composition of employment does not have a strong consequence for the low pay of women at the aggregate level. That is, women are not low paid because and only when they work in female jobs. As figures 3 and 4 clearly show, in all types of jobs (female, 
mixed and male) women face gender wage differentials. Women working in female jobs are not at a larger disadvantage relative to their male counterparts than women working in mixed and male jobs. If there is "systematic" gender discrimination in the labour market, it is against women, not just against women in female jobs. ${ }^{66}$

Second, we do find significant penalties to female work for males, and certain groups of females in some specifications. Therefore, the potential impact of selective pay equity programs may be greater for these individuals. As in many previous studies of comparable worth programs, these predictions are simulations and speculation based on inference from "pre-legislation" labour markets. Evaluations of the actual impacts of the pay equity initiatives of the 1990s will provide an important test of their validity. These, as well as further study into the reasons many female jobs in Canada do not attract a sizeable wage penalty, remain important topics for future research. ${ }^{67}$

${ }^{66}$ Using data from the Survey of Labour and Income Dynamics, Drolet (1999) has indeed found that even after controlling for a wide set of variables, including detailed experience variables, a substantial portion of gender wage differentials remains unexplained. That part of the gender wage gap is usually thought to be a discriminatory wage differential.

${ }^{67}$ Baker and Fortin (1999a) investigate the effects of Ontario's extension of pay equity to the private sector in the early 1990 s. 


\section{REFERENCES}

Acemoglu, Daron and Joshua Angrist, "How Large Are The Social Returns to Education? Evidence from Compulsory Schooling Laws," Mimeo, Department of Economics, MIT January 2000.

Baker, Michael and Nicole M. Fortin, "Comparable Worth Comes to the Private Sector: The Case of Ontario," Working Paper, presented at the 4th SOLE Meetings, Boston May 1999.

and __, "Women's Wages in Women's Work: A US-Canada Comparison of the Roles of Unions and "Public Goods" Sector Jobs," American Economic Review - AEA Papers and Proceedings, May 1999, 89 (2), 198-223.

and _ _ "Gender Composition and Wages: Why is Canada Different from the United States?," Research Paper 140, Analytical Studies Branch, Statistics Canada, Ottawa ON, April 2000.

, Dwayne Benjamin, Andrée Desaulniers, and Mary Grant, "The Distribution of the Male/Female Earnings Differential: 1970-1990," Working Paper 9307, Department of Economics, University of Toronto, Toronto, Ontario August 1993.

_,$\ldots$ _ $\ldots$, and _ _ "The Distribution of the Male/Female Earnings Differential: 1970-1990," Canadian Journal of Economics, August 1995, 28, 479-501.

Blau, Francine D. and Andrea H. Beller, "Trends in Earnings Differentials by Gender, 1971-1981," Industrial and Labor Relations Review, 1988, 41, 513-529.

Canada, Canadian Classification and Dictionary of Occupations: Guide, Vol. 1-2, Ottawa: Dept. of Manpower and Immigration, 1971-1973. 
— Canadian Classification and Dictionary of Occupations: Occupations in major groups : 11 management and administration, 21 natural sciences, engineering and mathematics, 33 art, literature and performing arts, 37 sport and recreation, 41 clerical, 51 sales, 81/82 processing, 83 machining, 85 product fabricating, assembling and repairing, Ottawa: Employment and Immigration Canada, 1971, c1985.

— Canadian Classification and Dictionary of Occupations: Occupations in major groups : 91 transport equipment operating, 93 material handling, 95 other crafts and equipment operating, 99 occupations not elsewhere classified, Ottawa: Employment and Immigration Canada, 1971, c1985.

— Canadian Classification and Dictionary of Occupations: Construction occupations, Ottawa: Employment and Immigration Canada, 1977.

_ Canadian Classification and Dictionary of Occupations: Primary products occupations, Ottawa: Employment and Immigration Canada, 1978.

_ Canadian Classification and Dictionary of Occupations: Occupations in major groups : 23 social sciences, 25 religion, 27 teaching, 31 medicine and health, Ottawa: Employment and Immigration Canada, 1980.

Carrington, William J. and Kenneth R. Troske, "Gender Segregation in Small Firms," Journal of Human Resources, 1995, 30 (3), 329-365.

CCH Canadian Limited, "Canadian Labour Law Reporter," Technical Report, North York, Ontario 1997.

\section{Cheng, Shih-Neng, Peter F. Orazem, J.Peter Mattila, and Jeffrey J. Greig,} "Measurement Error in Job Evaluation and the Gender Wage Gap," Working Paper, Iowa State University March 1997. 
Cihon, Patrick, "Comparable Worth: The Quebec Experience," Journal of Collective Negotiations in the Public Sector, 1988, 17 (3), 249-255.

DiNardo, John, Nicole Fortin, and Thomas Lemieux, "Labor Market Institutions and the Distribution of Wages: A Semiparametric Approach," Econometrica, September 1996, 64, 1001-1044.

Doiron, Denise J. and W. Craig Riddell, "The Impact of Unionization on MaleFemale Earnings Differences in Canada," Journal of Human Resources, 1994, 29 (2), $505-534$.

Drolet, Marie, "The Persistent Gap: New Evidence on the Canadian Gender Gap," Working Paper, Business and Labour Market Analysis Division, Statistics Canada, Ottawa, ON November 1999.

Fillmore, Catherine J., "Gender Differences in Earnings: A Re-analysis and Prognosis for Canadian Women," Canadian Journal of Sociology, 1990, 15 (3), 275-299.

Gibbs, Michael and Wallace Hendricks, "Are Administrative Pay Systems a Veil?," Working Paper, Institute of Labor \& Industrial Relations, University of Illinois, Champaign, Il. March 1997.

Hodson, Randy and Paula England, "Industrial Structure and Sex Differences in Earnings," Industrial Relations, Winter 1986, 25 (1), 16-32.

Hunter, Alfred A. and Michael C. Manley, "On the Task Content of Work," Canadian Review of Sociology \&s Anthropology, 1986, 23 (1), 47-71.

Johnson, George and Gary Solon, "Estimates of the Direct Effects of Comparable Worth Policy," American Economic Review, December 1986, 76 (5), 1117-1125. 
Kidd, Michael and Michael Shannon, "An Update and Extension of the Canadian Evidence on Gender Wage Differentials," Canadian Journal of Economics, November 1994, 27, 919-938.

Killingsworth, Mark R., The Economics of Comparable Worth, Kalamazoo, MI: W.E. Upjohn Institute, 1990.

Leigh, J. Paul, "Do Union Members Receive Compensating Wages for Accepting Employment in Strike-prone or Hazardous Industries?," Social Science Quarterly, March $1984,65(1), 87-99$.

Lemieux, Thomas, "Unions and Wage Inequality in Canada and the United States," in David Card and Richard Freeman, eds., Small Differences that Matter: Labor Markets and Income Maintenance in Canada and the United States, Chicago: University of Chicago Press and NBER, 1993.

Macpherson, David A. and Barry T. Hirsch, "Wages and Gender Composition: Why Do Women's Jobs Pay Less?," Journal of Labor Economics, July 1995, 13 (3), $426-471$.

Miller, Anne, Donald J. Treiman, Pamela S. Cain, and Patricia A. Ross, Work, Jobs, and Occupations: A Critical Review of Occupational Titles, Washington, D.C.: National Academy Press, 1980.

Moretti, Enrico, "Estimating the Social Return to Education: Evidence from Repeated Cross-Sectional and Longitudinal Data," Center for Labor Economics Working Paper 22, University of California, Berkeley, Berkeley, CA November 1999.

Moulton, Brent R., "Random Group Effects and the Precision of Regression Estimates," Journal of Econometrics, 1986, 32, 385-397. 
Reilly, Kevin T. and Tony S. Wirjanto, "Does More Mean Less? The Male/Female Wage Gap and the Proportion of Females at the Establishment Level," Canadian Journal of Economics, August 1999, 32 (4), 906-929.

Riddell, W. Craig, "Unionization in Canada and the United States: A Tale of Two Countries," in Richard B. Freeman and David Card, eds., Small Differences That Matter, Chicago: University of Chicago Press, 1993, pp. 109-148.

Symes, Beth, "Pay Equity in Canada," in Michael G. Abbott, ed., Pay Equity: Means and Ends, Kingston, Ontario: John Deutsch Institute for the Study of Economic Policy, 1990, pp. 21-30.

Weiner, Nan and Morley Gunderson, Pay Equity: Issues, Options and Experience, Toronto: Butterworths, 1990.

Wooldridge, Jeffrey M., "Asymptotic Properties of Weighted M-Estimators for Standard Stratified Samples," Working Paper, Michigan State University April 1998. 
TABLE 1

Canada/U.S. Comparison of Mean Wages, Gender Composition, Wage-Composition Relationship and Wage Gap by Job Types

\begin{tabular}{|c|c|c|c|c|c|c|c|c|c|c|c|}
\hline \multirow[b]{2}{*}{ Sample } & \multicolumn{5}{|c|}{ Women } & \multicolumn{5}{|c|}{ Men } & \multirow{2}{*}{$\begin{array}{c}\text { Female/ } \\
\text { Male } \\
\text { Wage Ratic }\end{array}$} \\
\hline & $N$ & Wage & PFEM & \multicolumn{2}{|c|}{$\widehat{\gamma}$} & $N$ & Wage & PFEM & \multicolumn{2}{|c|}{$\hat{\gamma}$} & \\
\hline \multicolumn{12}{|c|}{ 198\%:Canada } \\
\hline All jobs & 17810 & 9.87 & .676 & .006 & $(.061)$ & 21500 & 13.03 & .254 & -.130 & $(.052)$ & .758 \\
\hline Female jobs & 10801 & 9.95 & .858 & -.006 & $(.337)$ & 1627 & 12.36 & .773 & -.342 & $(.427)$ & .805 \\
\hline Mixed jobs & 5617 & 9.47 & .467 & -.792 & $(.369)$ & 6277 & 13.04 & .437 & -.492 & $(.359)$ & .726 \\
\hline Male jobs & 1392 & 10.76 & .190 & .758 & $(.251)$ & 13596 & 13.11 & .091 & .110 & $(.151)$ & .821 \\
\hline \multicolumn{12}{|c|}{ 1988:Canada } \\
\hline All jobs & 14868 & 10.88 & .668 & -.028 & $(.060)$ & 17739 & 14.23 & .251 & -.145 & $(.052)$ & .765 \\
\hline Female jobs & 8815 & 10.91 & .857 & -.082 & $(.320)$ & 1324 & 13.94 & .777 & -.603 & $(.399)$ & .783 \\
\hline Mixed jobs & 4876 & 10.62 & .465 & -.992 & $(.381)$ & 4963 & 13.89 & .435 & -.780 & $(.364)$ & .765 \\
\hline Male jobs & 1177 & 11.80 & .189 & .913 & $(.156)$ & 11452 & 14.41 & .099 & .175 & $(.156)$ & .819 \\
\hline \multicolumn{12}{|c|}{ 1987:United States } \\
\hline All jobs & 80009 & 9.70 & .675 & -.228 & $(.062)$ & 87713 & 13.55 & .265 & -.022 & $(.069)$ & .716 \\
\hline Female jobs & 50877 & 9.07 & .841 & .175 & $(.271)$ & 7899 & 11.76 & .742 & -.844 & $(.315)$ & .771 \\
\hline Mixed jobs & 22875 & 10.90 & .438 & -.065 & $(.318)$ & 29615 & 15.14 & .405 & -.199 & $(.377)$ & .719 \\
\hline Male jobs & 6257 & 10.53 & .191 & -.501 & $(.295)$ & 50199 & 12.90 & .108 & -.130 & $(.228)$ & .816 \\
\hline \multicolumn{12}{|c|}{ 1988:United States } \\
\hline All jobs & 76979 & 10.16 & .670 & -.227 & $(.062)$ & 84009 & 14.01 & .266 & -.028 & $(.069)$ & .725 \\
\hline Female jobs & 48518 & 9.52 & .839 & .130 & $(.278)$ & 7498 & 12.00 & .743 & -.812 & $(.337)$ & .793 \\
\hline Mixed jobs & 22311 & 11.33 & .436 & -.059 & $(.310)$ & 28341 & 15.69 & .404 & -.205 & $(.381)$ & .722 \\
\hline Male jobs & 6150 & 10.93 & .187 & -.292 & $(.288)$ & 48170 & 13.35 & .108 & -.093 & $(.231)$ & .818 \\
\hline
\end{tabular}

\section{NOTES}

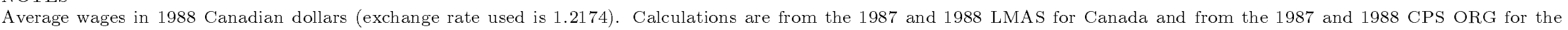

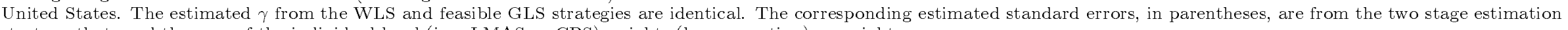
strategy that used the sum of the individual level (i.e., LMAS or CPS) weights (by occupation) as weights. 
TABLE 2

Means of Selected Variables

\begin{tabular}{|c|c|c|c|c|}
\hline \multirow[b]{2}{*}{ Variable } & \multicolumn{2}{|c|}{ Women } & \multicolumn{2}{|c|}{ Men } \\
\hline & 1987 & 1988 & 1987 & 1988 \\
\hline Wage (1988 Canadian\$) & 10.32 & 10.88 & 13.57 & 14.23 \\
\hline Age & 36.4 & 36.5 & 37.2 & 37.2 \\
\hline \multicolumn{5}{|l|}{ Education: } \\
\hline Primary & .070 & .063 & .108 & .104 \\
\hline Some High School & .104 & .101 & .142 & .130 \\
\hline High School Grad & .381 & .362 & .348 & .341 \\
\hline Some Post-Secondary & .107 & .101 & .096 & .097 \\
\hline Post-Secondary Degree & .189 & .210 & .143 & .162 \\
\hline University Degree & .149 & .164 & .164 & .167 \\
\hline Part-time & .217 & .226 & .041 & .042 \\
\hline Married & .670 & .665 & .710 & .690 \\
\hline Visible Minority & .054 & .052 & .052 & .051 \\
\hline Metropolitain Área & .652 & .731 & .630 & .703 \\
\hline \multicolumn{5}{|l|}{ Industrial Sector: } \\
\hline $\begin{array}{l}\text { Agriculture, } \\
\text { Forestry and Fisheries }\end{array}$ & .013 & .011 & .025 & .023 \\
\hline Mining & .006 & .006 & .029 & .029 \\
\hline Construction & .013 & .017 & .086 & .085 \\
\hline \multicolumn{5}{|l|}{ Manufact uring } \\
\hline Nondurable & .080 & .073 & .102 & .110 \\
\hline Durable & .049 & .047 & .156 & .159 \\
\hline $\begin{array}{l}\text { Transportation and } \\
\text { public utilities }\end{array}$ & .050 & .046 & .111 & .116 \\
\hline Trade & .163 & .161 & .156 & .156 \\
\hline FIRE & .088 & .088 & .042 & .040 \\
\hline $\begin{array}{l}\text { Business and } \\
\text { professional services }\end{array}$ & .056 & .062 & .042 & .043 \\
\hline Consumer services & .117 & .121 & .061 & .055 \\
\hline $\begin{array}{l}\text { Medical, welfare, and } \\
\text { educational services }\end{array}$ & .294 & .291 & .097 & .098 \\
\hline Public administration & .070 & .075 & .093 & .086 \\
\hline Federal & .020 & .020 & .041 & .042 \\
\hline Provincial (State) & .028 & .029 & .029 & .023 \\
\hline Local & .016 & .016 & .034 & .035 \\
\hline Union coverage & .361 & .371 & .441 & .452 \\
\hline Tenure & 5.67 & 5.78 & 7.67 & 8.00 \\
\hline \multicolumn{5}{|l|}{ Establishment Size: } \\
\hline$s<20$ & .379 & .376 & .321 & .300 \\
\hline $20<=s<100$ & .316 & .298 & .330 & .320 \\
\hline $100<=s<500$ & .206 & .203 & .231 & .237 \\
\hline$s>=500$ & .099 & .122 & .118 & .142 \\
\hline No. of observations & 17,810 & 14,868 & 21,501 & 17,739 \\
\hline
\end{tabular}




\section{TABLE 3}

Estimated effects of gender composition on wage levels in Canada

\begin{tabular}{|c|c|c|c|c|c|c|c|c|c|}
\hline & Specification: & WLS & GLS0 & GLS1 & GLS2 & WLS & GLS0 & GLS1 & GLS2 \\
\hline \multirow{2}{*}{$\begin{array}{l}\text { Women: } \\
1 .\end{array}$} & & \multicolumn{4}{|c|}{1987} & \multicolumn{4}{|c|}{1988} \\
\hline & Human capital & $\begin{array}{l}-.031 \\
(.012)\end{array}$ & $\begin{array}{l}-.146 \\
(.057)\end{array}$ & $\begin{array}{l}-.091 \\
(.052)\end{array}$ & $\begin{array}{l}-.004 \\
(.047)\end{array}$ & $\begin{array}{l}-.035 \\
(.014)\end{array}$ & $\begin{array}{l}-.013 \\
(.060)\end{array}$ & $\begin{array}{l}-.013 \\
(.055)\end{array}$ & $\begin{array}{l}-.023 \\
(.046)\end{array}$ \\
\hline 2. & $\begin{array}{r}1+\text { Sectoral } \\
\text { controls }\end{array}$ & $\begin{array}{l}-.096 \\
(.012)\end{array}$ & $\begin{array}{l}-.108 \\
(.051)\end{array}$ & $\begin{array}{l}-.056 \\
(.045)\end{array}$ & $\begin{array}{l}-.040 \\
(.036)\end{array}$ & $\begin{array}{l}-.108 \\
(.013)\end{array}$ & $\begin{array}{l}-.035 \\
(.054)\end{array}$ & $\begin{array}{l}-.012 \\
(.050)\end{array}$ & $\begin{array}{l}-.067 \\
(.037)\end{array}$ \\
\hline 3. & $\begin{array}{l}2+\text { Individual } \\
\text { characteristics }\end{array}$ & $\begin{array}{l}-.094 \\
(.012)\end{array}$ & $\begin{array}{l}-.120 \\
(.049)\end{array}$ & $\begin{array}{l}-.066 \\
(.043)\end{array}$ & $\begin{array}{l}-.041 \\
(.034)\end{array}$ & $\begin{array}{l}-.101 \\
(.013)\end{array}$ & $\begin{array}{l}-.033 \\
(.051)\end{array}$ & $\begin{array}{l}-.012 \\
(.047)\end{array}$ & $\begin{array}{l}-.062 \\
(.035)\end{array}$ \\
\hline \multirow[t]{2}{*}{4.} & $\begin{array}{l}3+\text { Occupational } \\
\text { averages }\end{array}$ & $\begin{array}{l}-.105 \\
(.018)\end{array}$ & $\begin{array}{l}-.117 \\
(.058)\end{array}$ & $\begin{array}{l}-.095 \\
(.053)\end{array}$ & $\begin{array}{l}-.108 \\
(.029)\end{array}$ & $\begin{array}{l}-.069 \\
(.017)\end{array}$ & $\begin{array}{l}-.075 \\
(.063)\end{array}$ & $\begin{array}{l}-.077 \\
(.059)\end{array}$ & $\begin{array}{l}-.068 \\
(.031)\end{array}$ \\
\hline & No. of occupations & \multicolumn{4}{|c|}{380} & \multicolumn{4}{|c|}{378} \\
\hline \multicolumn{2}{|l|}{ Men: } & \multicolumn{4}{|c|}{1987} & \multicolumn{4}{|c|}{1988} \\
\hline 1. & Human capital & $\begin{array}{l}-.285 \\
(.012)\end{array}$ & $\begin{array}{l}-.207 \\
(.042)\end{array}$ & $\begin{array}{l}-.229 \\
(.040)\end{array}$ & $\begin{array}{l}-.217 \\
(.036)\end{array}$ & $\begin{array}{l}-.298 \\
(.014)\end{array}$ & $\begin{array}{l}-.274 \\
(.042)\end{array}$ & $\begin{array}{l}-.252 \\
(.040)\end{array}$ & $\begin{array}{l}-.228 \\
(.038)\end{array}$ \\
\hline 2. & $\begin{array}{r}1+\begin{array}{l}\text { Sectoral } \\
\text { Controls }\end{array}\end{array}$ & $\begin{array}{l}-.123 \\
(.013)\end{array}$ & $\begin{array}{l}-.081 \\
(.039)\end{array}$ & $\begin{array}{l}-.099 \\
(.031)\end{array}$ & $\begin{array}{l}-.052 \\
(.033)\end{array}$ & $\begin{array}{l}-.165 \\
(.011)\end{array}$ & $\begin{array}{l}-.164 \\
(.039)\end{array}$ & $\begin{array}{l}-.141 \\
(.037)\end{array}$ & $\begin{array}{l}-.104 \\
(.034)\end{array}$ \\
\hline 3. & $\begin{array}{l}2+\text { Individual } \\
\text { characteristics }\end{array}$ & $\begin{array}{l}-.129 \\
(.013)\end{array}$ & $\begin{array}{l}-.076 \\
(.037)\end{array}$ & $\begin{array}{l}-.095 \\
(.034)\end{array}$ & $\begin{array}{l}-.067 \\
(.030)\end{array}$ & $\begin{array}{l}-.149 \\
(.016)\end{array}$ & $\begin{array}{l}-.151 \\
(.037)\end{array}$ & $\begin{array}{l}-.131 \\
(.035)\end{array}$ & $\begin{array}{l}-.110 \\
(.031)\end{array}$ \\
\hline \multirow[t]{2}{*}{4.} & $\begin{array}{l}3+\text { Occupational } \\
\text { averages }\end{array}$ & $\begin{array}{l}-.097 \\
(.018)\end{array}$ & $\begin{array}{l}-.112 \\
(.047)\end{array}$ & $\begin{array}{l}-.115 \\
(.043)\end{array}$ & $\begin{array}{l}-.095 \\
(.033)\end{array}$ & $\begin{array}{l}-.166 \\
(.019)\end{array}$ & $\begin{array}{l}-.246 \\
(.047)\end{array}$ & $\begin{array}{l}-.204 \\
(.044)\end{array}$ & $\begin{array}{l}-.161 \\
(.033)\end{array}$ \\
\hline & No. of occupations & \multicolumn{4}{|c|}{473} & \multicolumn{4}{|c|}{456} \\
\hline
\end{tabular}

\section{NOTES}

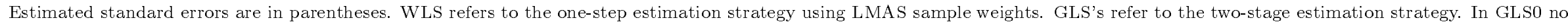

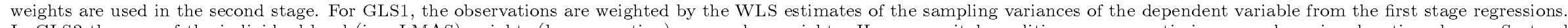

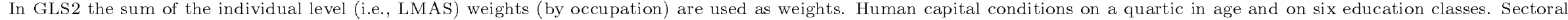

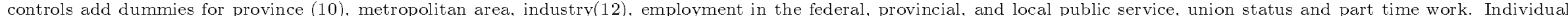

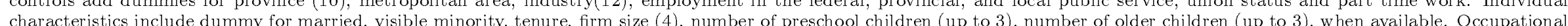
averages are the averages of the individual explanatory variables by 4 -digit occupation. 
TABLE 4

The Role of CCDO Occupational Characteristics in the Effect of Gender Composition on Wages in Canada - 1988

\begin{tabular}{|c|c|c|c|c|c|}
\hline & \multirow[b]{2}{*}{ Specification: } & \multicolumn{2}{|c|}{ Women } & \multicolumn{2}{|c|}{ Men } \\
\hline & & WLS & GLS2 & WLS & GLS2 \\
\hline 5. & $3+$ Educational requirements $^{a}$ & $\begin{array}{l}-.013 \\
(.014)\end{array}$ & $\begin{array}{l}-.011 \\
(.026)\end{array}$ & $\begin{array}{l}-.145 \\
(.015)\end{array}$ & $\begin{array}{l}-.177 \\
(.025)\end{array}$ \\
\hline 6. & $5+\operatorname{Hazards}^{b}$ & $\begin{array}{c}.011 \\
(.015)\end{array}$ & $\begin{array}{c}.019 \\
(.028)\end{array}$ & $\begin{array}{l}-.109 \\
(.017)\end{array}$ & $\begin{array}{l}-.125 \\
(.032)\end{array}$ \\
\hline 7. & $6+$ Strength physical demands ${ }^{c}$ & $\begin{array}{l}-.026 \\
(.018)\end{array}$ & $\begin{array}{l}-.036 \\
(.028)\end{array}$ & $\begin{array}{l}-.102 \\
(.018)\end{array}$ & $\begin{array}{l}-.155 \\
(.030)\end{array}$ \\
\hline 8. & 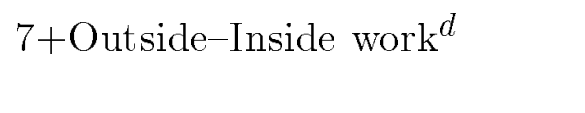 & $\begin{array}{l}-.037 \\
(.019)\end{array}$ & $\begin{array}{l}-.025 \\
(.032)\end{array}$ & $\begin{array}{l}-.098 \\
(.018)\end{array}$ & $\begin{array}{l}-.118 \\
(.034)\end{array}$ \\
\hline
\end{tabular}

Similar specifications

with full-set of occupational averages of individual characteristics

9. 4+Educational requirements ${ }^{a}-014-014-0-137$

$-.134$

$\begin{array}{llll}(.019) & (.033) \quad(.019) \quad(.034)\end{array}$

10. $9+$ Hazards $^{b}$

$\begin{array}{llll}.003 & .003 & -.119 & -.115\end{array}$

11. $10+$ Strength physical demands $c$

$(.035)$

$(.021)$

$-.021$

$-.019$

$-.106$

$-.103$

12. $11+$ Outside-Inside work ${ }^{d}$

(.040)

$(.022)$

$-.039$

$-.038$

$-.098$

$-.096$

No. of occupations

(.024)

$(.040)$

$(.022)$

(.039)

378

456

\section{NOTES}

WLS refers to the one-step estimation strategy using LMAS sample weights. The GLS2 estimates are from the feasible GLS strategy where the sum of the individual level (i.e., LMAS or CPS) weights (by occupation) are used as weights in the second stage. Estimated standard errors are reported in parentheses.

${ }^{a}$ Educational requirements include CCDO general educational development (GED), measured in years of education and specific vocational training (SVP), measured in months.

${ }^{b}$ Hazards is CCDO-EC 6.

${ }^{c}$ Strength and physical demands include the CCDO following physical demands (PA) codes: sedentary work-medium work PA-1: S,S-L,S-M, heavy work to PA-1: $\mathrm{H}$ and VH; bending to PA-3; visual skills to PA-7; and motor coordination to the sum of PA-2-4-8.

${ }^{d}$ Outside and inside work are the CCDO-EC 1 and denote work location. 


\section{TABLE 5}

Gender Composition Coefficients on Wages among Alternative Worker Groups - 1988

\begin{tabular}{|c|c|c|c|c|c|c|c|c|}
\hline $\begin{array}{l}\text { Specification: } \\
\text { Group }\end{array}$ & $N C$ & No controls & $\begin{array}{c}\text { (1) } \\
\text { Sectoral } \\
\text { Controls }\end{array}$ & $\begin{array}{c}(2) \\
\text { Occupational } \\
\text { Controls }\end{array}$ & $N C$ & No controls & $\begin{array}{c}\text { (1) } \\
\text { Sectoral } \\
\text { Controls }\end{array}$ & $\begin{array}{c}(2) \\
\text { Occupational } \\
\text { Controls }\end{array}$ \\
\hline & & & Women & & & & Men & \\
\hline \multicolumn{9}{|l|}{ Age: } \\
\hline $16-29$ & 307 & $\begin{array}{l}-.075 \\
(.061)\end{array}$ & $\begin{array}{l}-.057 \\
(.041)\end{array}$ & $\begin{array}{l}.039 \\
(.040)\end{array}$ & 380 & $\begin{array}{l}-.323 \\
(.052)\end{array}$ & $\begin{array}{l}-.192 \\
(.036)\end{array}$ & $\begin{array}{l}-.181 \\
(.045)\end{array}$ \\
\hline $30-44$ & 307 & $\begin{array}{l}-.059 \\
(.071)\end{array}$ & $\begin{array}{l}-.109 \\
(.047)\end{array}$ & $\begin{array}{l}-.013 \\
(.046)\end{array}$ & 417 & $\begin{array}{l}-.037 \\
.051)\end{array}$ & $\begin{array}{l}-.055 \\
(.042)\end{array}$ & $\begin{array}{l}-.118 \\
(.048)\end{array}$ \\
\hline $44-69$ & 246 & $\begin{array}{l}.102 \\
(.079)\end{array}$ & $\begin{array}{l}.009 \\
(.055)\end{array}$ & $\begin{array}{l}-.047 \\
(.061)\end{array}$ & 392 & $\begin{array}{l}-.084 \\
(.067)\end{array}$ & $\begin{array}{l}-.072 \\
(.053)\end{array}$ & $\begin{array}{l}-.048 \\
(.057)\end{array}$ \\
\hline \multicolumn{9}{|l|}{ Education: } \\
\hline Drop-out & 230 & $\begin{array}{l}-.113 \\
(.060)\end{array}$ & $\begin{array}{l}-.087 \\
(.052)\end{array}$ & $\begin{array}{l}-.047 \\
(.059)\end{array}$ & 355 & $\begin{array}{l}-.518 \\
(.054)\end{array}$ & $\begin{array}{l}-.257 \\
(.043)\end{array}$ & $\begin{array}{l}-.205 \\
(.051)\end{array}$ \\
\hline High School & 294 & $\begin{array}{l}-.028 \\
(.052)\end{array}$ & $\begin{array}{l}-.032 \\
(.038)\end{array}$ & $\begin{array}{l}.036 \\
(.038)\end{array}$ & 394 & $\begin{array}{l}-.322 \\
(055)\end{array}$ & $\begin{array}{l}-.094 \\
(.040)\end{array}$ & $\begin{array}{l}-.159 \\
(.043)\end{array}$ \\
\hline $\begin{array}{l}\text { Post- } \\
\text { secondary }\end{array}$ & 260 & $\begin{array}{l}.045 \\
(.063)\end{array}$ & $\begin{array}{l}-.001 \\
(.049)\end{array}$ & $\begin{array}{l}.050 \\
(.051)\end{array}$ & 365 & $\begin{array}{l}-.294 \\
(.054)\end{array}$ & $\begin{array}{l}-.165 \\
(.040)\end{array}$ & $\begin{array}{l}-.116 \\
(.061)\end{array}$ \\
\hline University & 179 & $\begin{array}{l}-.095 \\
(.081)\end{array}$ & $\begin{array}{l}-.184 \\
(.066)\end{array}$ & $\begin{array}{l}.035 \\
(.087)\end{array}$ & 253 & $\begin{array}{l}-.184 \\
(.084)\end{array}$ & $\begin{array}{l}-.177 \\
(.075)\end{array}$ & $\begin{array}{l}-.006 \\
(.083)\end{array}$ \\
\hline \multicolumn{9}{|c|}{ Union coverage status: } \\
\hline Nonunion & 342 & $\begin{array}{c}-.182 \\
(.059)\end{array}$ & $\begin{array}{c}-.136 \\
(.042)\end{array}$ & $\begin{array}{c}-.029 \\
(.041)\end{array}$ & 415 & $\begin{array}{c}-.211 \\
(.071)\end{array}$ & $\begin{array}{l}-.214 \\
(.046)\end{array}$ & $\begin{array}{c}-.240 \\
(.053)\end{array}$ \\
\hline Union & 287 & $\begin{array}{l}.025 \\
(.061)\end{array}$ & $\begin{array}{l}.044 \\
(.060)\end{array}$ & $\begin{array}{l}.022 \\
(.044)\end{array}$ & 416 & $\begin{array}{l}-.016 \\
(.038)\end{array}$ & $\begin{array}{l}.018 \\
(.030)\end{array}$ & $\begin{array}{l}-.127 \\
(.032)\end{array}$ \\
\hline \multicolumn{9}{|l|}{ Hours status: } \\
\hline Part-time & 211 & $\begin{array}{l}.353 \\
(.099)\end{array}$ & $\begin{array}{l}.169 \\
(.066)\end{array}$ & $\begin{array}{l}-.095 \\
(.076)\end{array}$ & 181 & $\begin{array}{l}-.168 \\
(.122)\end{array}$ & $\begin{array}{l}-.148 \\
(.096)\end{array}$ & $\begin{array}{l}-.427 \\
(.120)\end{array}$ \\
\hline Full-time & 373 & $\begin{array}{l}-.097 \\
(.058)\end{array}$ & $\begin{array}{l}-.107 \\
(.035)\end{array}$ & $\begin{array}{l}-.034 \\
(.031)\end{array}$ & 456 & $\begin{array}{l}-.117 \\
(.051)\end{array}$ & $\begin{array}{l}-.094 \\
(.034)\end{array}$ & $\begin{array}{l}-.093 \\
(.035)\end{array}$ \\
\hline
\end{tabular}


TABLE 5 (continued)

\begin{tabular}{|c|c|c|c|c|c|c|c|c|}
\hline & & & (1) & $(2)$ & & & (1) & $(2)$ \\
\hline $\begin{array}{l}\text { Specification: } \\
\text { Group }\end{array}$ & $N C$ & No controls & $\begin{array}{l}\text { Sectoral } \\
\text { Controls }\end{array}$ & $\begin{array}{l}\text { Occupational } \\
\text { Controls }\end{array}$ & $N C$ & No controls & $\begin{array}{l}\text { Sectoral } \\
\text { Controls }\end{array}$ & $\begin{array}{l}\text { Occupational } \\
\text { Controls }\end{array}$ \\
\hline & & & Women & & & & Men & \\
\hline \multicolumn{9}{|l|}{ Establishment Size: } \\
\hline $\begin{array}{l}\text { Less than } \\
100 \text { employees }\end{array}$ & 322 & $\begin{array}{l}-.034 \\
(.062)\end{array}$ & $\begin{array}{l}-.074 \\
(.042)\end{array}$ & $\begin{array}{l}-.048 \\
(.045)\end{array}$ & 404 & $\begin{array}{l}-.258 \\
(.057)\end{array}$ & $\begin{array}{l}-.125 \\
(.042)\end{array}$ & $\begin{array}{l}-.231 \\
(.047)\end{array}$ \\
\hline $\begin{array}{l}\text { At least } \\
100 \text { employees }\end{array}$ & 321 & $\begin{array}{l}-.007 \\
(.060)\end{array}$ & $\begin{array}{l}-.047 \\
(.041)\end{array}$ & $\begin{array}{l}-.013 \\
(.036)\end{array}$ & 435 & $\begin{array}{l}-.127 \\
(.048)\end{array}$ & $\begin{array}{l}-.078 \\
(.034)\end{array}$ & $\begin{array}{l}-.081 \\
(.037)\end{array}$ \\
\hline \multicolumn{9}{|l|}{ Industrial Sectors: } \\
\hline $\begin{array}{l}\text { Public } \\
\text { Administration }\end{array}$ & 138 & $\begin{array}{l}-.266 \\
(.078)\end{array}$ & $\begin{array}{l}-.204 \\
(.057)\end{array}$ & $\begin{array}{l}.026 \\
(.065)\end{array}$ & 184 & $\begin{array}{l}.000 \\
(.079)\end{array}$ & $\begin{array}{l}-.155 \\
(.053)\end{array}$ & $\begin{array}{l}-.030 \\
(.061)\end{array}$ \\
\hline $\begin{array}{l}\text { Medical, } \\
\text { Welfare, and } \\
\text { Educational } \\
\text { Services }\end{array}$ & 136 & $\begin{array}{l}-.062 \\
(.111)\end{array}$ & $\begin{array}{l}.041 \\
(.072)\end{array}$ & $\begin{array}{c}.009 \\
(.076)\end{array}$ & 159 & $\begin{array}{c}.195 \\
(.112)\end{array}$ & $\begin{array}{l}.208 \\
(.091)\end{array}$ & $\begin{array}{l}.166 \\
(.083)\end{array}$ \\
\hline $\begin{array}{l}\text { Other } \\
\text { Sectors }\end{array}$ & 364 & $\begin{array}{l}-.214 \\
(.053)\end{array}$ & $\begin{array}{l}-.147 \\
(.038)\end{array}$ & $\begin{array}{l}-.022 \\
(.032)\end{array}$ & 427 & $\begin{array}{l}-.348 \\
(.054)\end{array}$ & $\begin{array}{l}-.176 \\
(.038)\end{array}$ & $\begin{array}{l}-.231 \\
(.035)\end{array}$ \\
\hline
\end{tabular}

\section{NOTES}

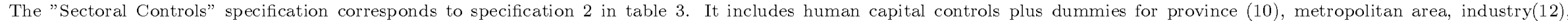

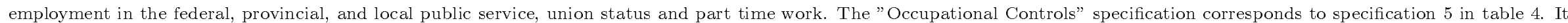

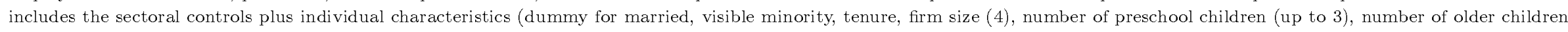

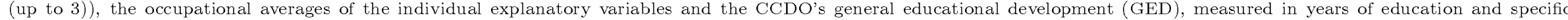

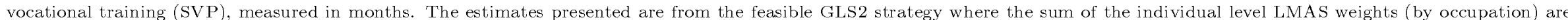
used as weights in the second stage. Estimated standard errors are in parentheses. $N C$ is the number of occupations. 
TABLE 6

Longitudinal Estimates of the Effect of Gender Composition (PFEM) on Wage Levels and of Changes in Gender Composition ( $\triangle \mathrm{PFEM}$ ) on Changes in Wage Levels

\begin{tabular}{|c|c|c|c|c|c|c|}
\hline \multirow[b]{3}{*}{ Specification } & \multicolumn{3}{|c|}{ Women } & \multicolumn{3}{|c|}{ Men } \\
\hline & \multicolumn{2}{|c|}{ Levels } & \multirow{2}{*}{$\begin{array}{l}\text { Changes } \\
\text { WLS }\end{array}$} & \multicolumn{2}{|c|}{ Levels } & \multirow{2}{*}{$\begin{array}{l}\text { Changes } \\
\text { WLS }\end{array}$} \\
\hline & WLS & GLS2 & & WLS & GLS2 & \\
\hline \multicolumn{7}{|c|}{ 1988-1989: Occupation Switchers } \\
\hline No controls & $\begin{array}{l}-.228 \\
(.060)^{a}\end{array}$ & $\begin{array}{l}-.228 \\
(.096)\end{array}$ & $\begin{array}{l}-.068 \\
(.044)^{a}\end{array}$ & $\begin{array}{l}-.081 \\
(.069)\end{array}$ & $\begin{array}{l}-.081 \\
(.098)\end{array}$ & $\begin{array}{l}-.200 \\
(.062)\end{array}$ \\
\hline 1: Human capital & $\begin{array}{l}-.219 \\
(.051)\end{array}$ & $\begin{array}{l}-.215 \\
(.079)\end{array}$ & $\begin{array}{l}-.068 \\
(.044)\end{array}$ & $\begin{array}{l}-.325 \\
(.063)\end{array}$ & $\begin{array}{l}-.238 \\
(.083)\end{array}$ & $\begin{array}{l}-.204 \\
(.062)\end{array}$ \\
\hline $\begin{aligned} 2: 1+ & \text { Sectoral } \\
& \text { Controls }\end{aligned}$ & $\begin{array}{l}-.217 \\
(.048)\end{array}$ & $\begin{array}{l}-.189 \\
(.070)\end{array}$ & $\begin{array}{l}-.059 \\
(.044)\end{array}$ & $\begin{array}{l}-.281 \\
(.064)\end{array}$ & $\begin{array}{l}-.174 \\
(.076)\end{array}$ & $\begin{array}{l}-.230 \\
(.063)\end{array}$ \\
\hline 4: $\begin{aligned} 2+ & \text { Individual } \\
& \text { Characteristics } \\
& + \text { Occupational } \\
& \text { Averages }\end{aligned}$ & $\begin{array}{l}-.244 \\
(.053)\end{array}$ & $\begin{array}{l}-.249 \\
(.067)\end{array}$ & $\begin{array}{l}-.066 \\
(.048)\end{array}$ & $\begin{array}{l}-.367 \\
(.074)\end{array}$ & $\begin{array}{l}-.369 \\
(.095)\end{array}$ & $\begin{array}{l}-.257 \\
(.069)\end{array}$ \\
\hline No. of observations & & 839 & & & 1008 & \\
\hline \multicolumn{7}{|l|}{ 1988-1989: All Workers } \\
\hline No controls & $\begin{array}{l}-.017 \\
(.019)\end{array}$ & $\begin{array}{l}-.017 \\
(.061)\end{array}$ & $\begin{array}{l}-.084 \\
(.021)^{a}\end{array}$ & $\begin{array}{l}-.044 \\
(.018)\end{array}$ & $\begin{array}{l}-.044 \\
(.048)\end{array}$ & $\begin{array}{l}-.226 \\
(.024)\end{array}$ \\
\hline 1: Human capital & $\begin{array}{l}-.050 \\
(.017)\end{array}$ & $\begin{array}{l}-.027 \\
(.047)\end{array}$ & $\begin{array}{l}-.085 \\
(.021)\end{array}$ & $\begin{array}{l}-.237 \\
(.017)\end{array}$ & $\begin{array}{l}-.158 \\
(.036)\end{array}$ & $\begin{array}{l}-.226 \\
(.024)\end{array}$ \\
\hline $\begin{aligned} 2: 1+ & \text { Sectoral } \\
& \text { Controls }\end{aligned}$ & $\begin{array}{l}-.092 \\
(.016)\end{array}$ & $\begin{array}{l}-.048 \\
(.039)\end{array}$ & $\begin{array}{l}-.074 \\
(.021)\end{array}$ & $\begin{array}{l}-.141 \\
(.017)\end{array}$ & $\begin{array}{l}-.060 \\
(.033)\end{array}$ & $\begin{array}{l}-.228 \\
(.025)\end{array}$ \\
\hline 4: $\begin{aligned} 2 & + \text { Individual } \\
& \text { Characteristics } \\
& + \text { Occupational } \\
& \text { Averages }\end{aligned}$ & $\begin{array}{l}-.091 \\
(.022)\end{array}$ & $\begin{array}{l}-.099 \\
(.035)\end{array}$ & $\begin{array}{l}-.059 \\
(.022)\end{array}$ & $\begin{array}{l}-.207 \\
(.021)\end{array}$ & $\begin{array}{c}-.202 \\
(.033)\end{array}$ & $\begin{array}{l}-.233 \\
(.025)\end{array}$ \\
\hline No. of observations & & 9791 & & & 11815 & \\
\hline
\end{tabular}

NOTES

Estimated standard errors are in parentheses. WLS refers to the one-step estimation strategy using LMAS sample weights. The GLS2 estimates are from the feasible GLS strategy where the sum of the individual level LMAS weights (by occupation) are used as weights in the second stage. The levels estimates are for 1989 . Because of the small number of observations relative to the number of occupations, singularity of the matrix of occupational changes made the two-stage strategy infeasible in the case of the changes. Estimated standard errors are in parentheses.

a Lower bound on the true standard errors. 


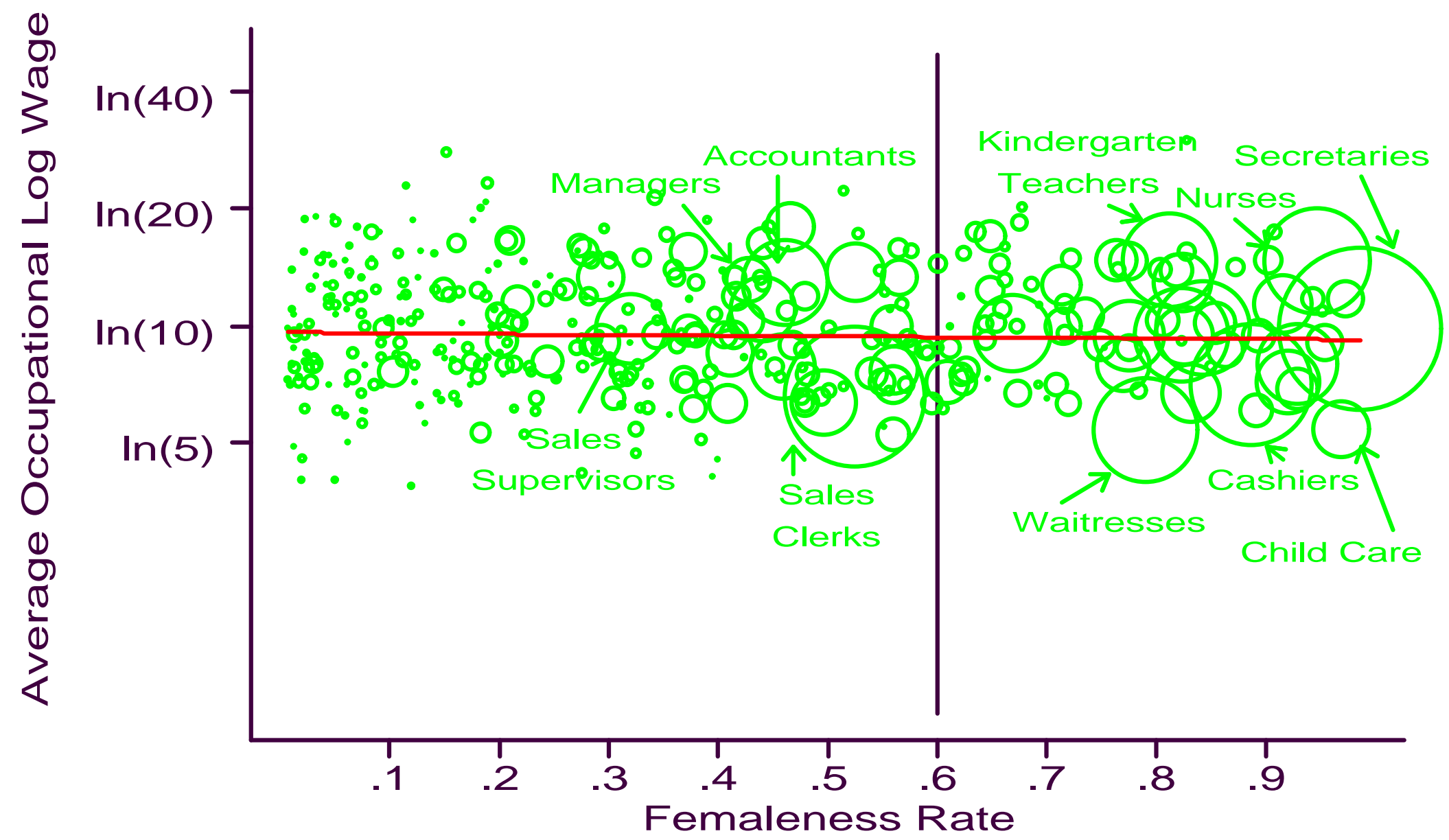

Figure 1. Effect of Gender Composition on Average Occupational Female Wages in Canada - 1988 


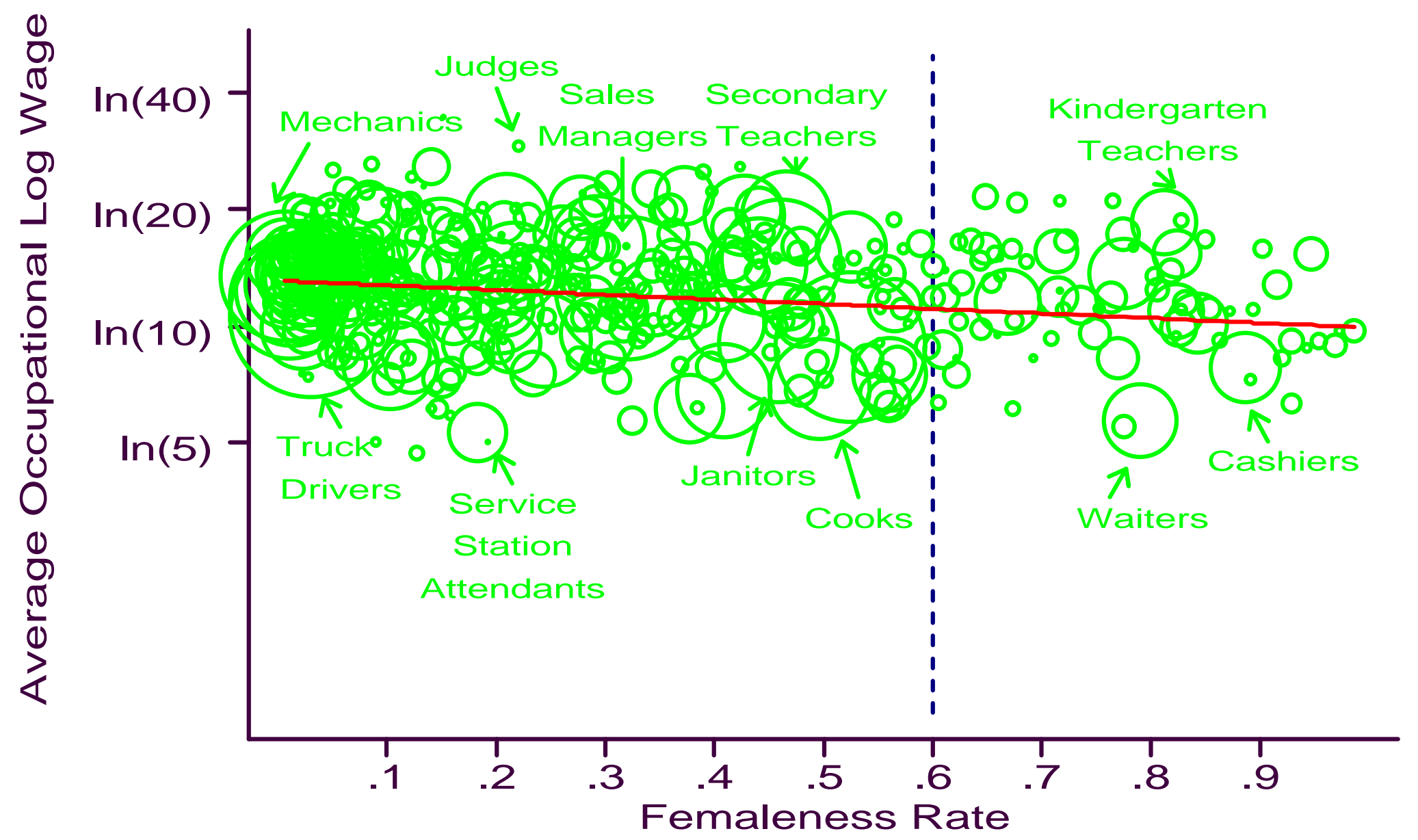

Figure 2. Effect of Gender Composition on Average Occupational Male Wages in Canada - 1988 


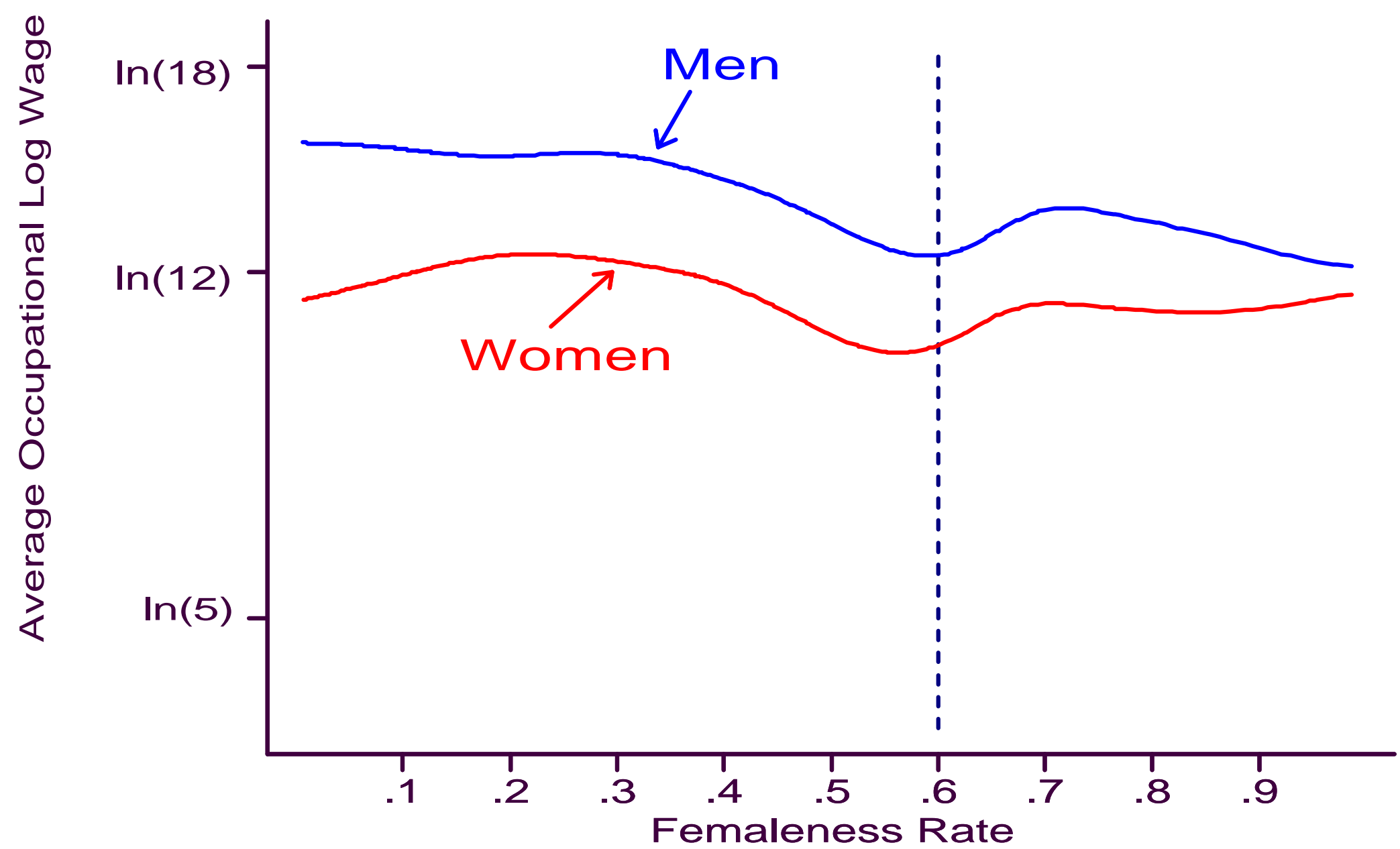

Figure 3. Weighted Kernel Regressions of Average Occupational Wages on Gender Composition in Canada - 1988 


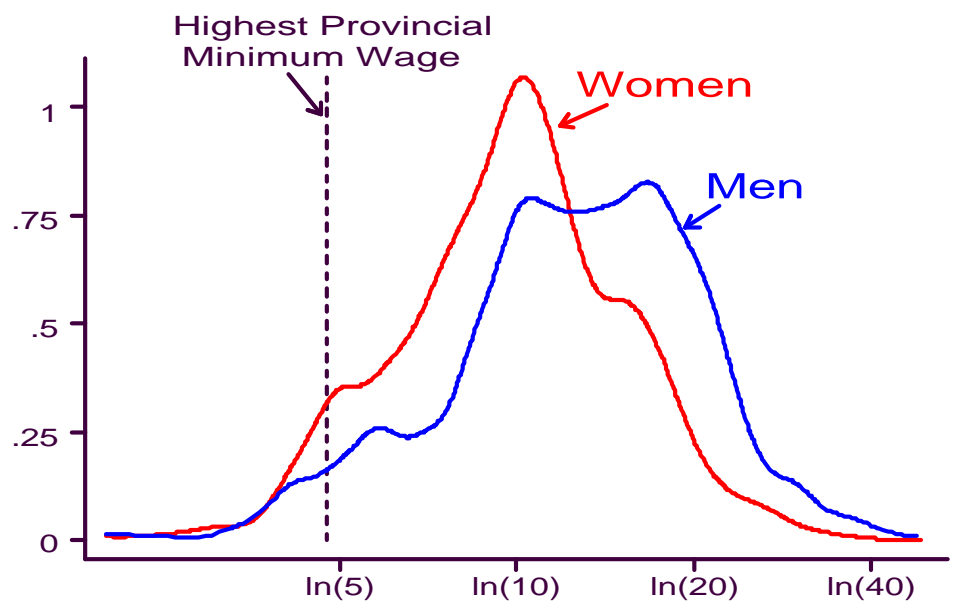

a) Female Jobs

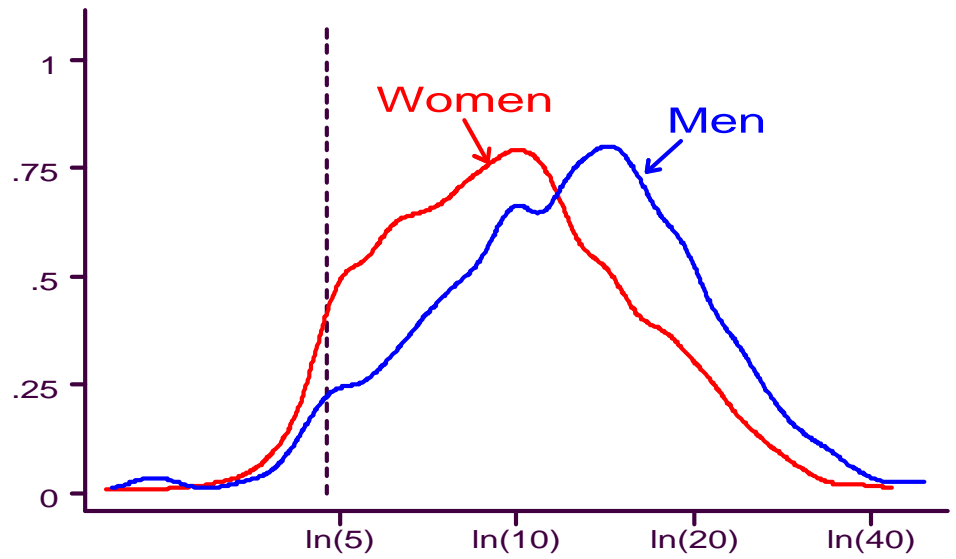

b) Mixed Jobs

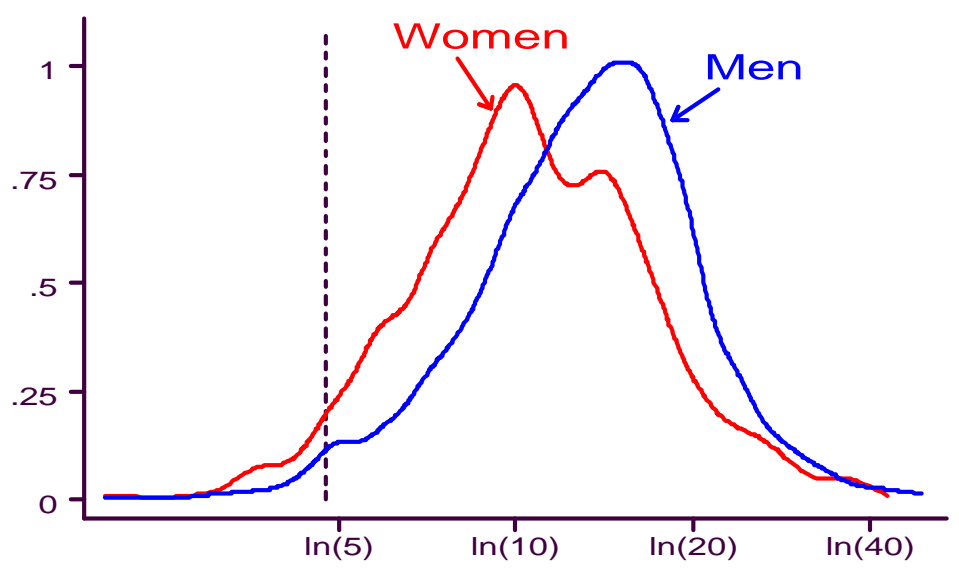

c) Male Jobs

Figure 4. Kernel Density Estimates of Log Hourly Wages by Job Types - 1988 


\section{Liste des publications au CIRANO *}

\section{Cahiers CIRANO / CIRANO Papers (ISSN 1198-8169)}

99c-1 Les Expos, l'OSM, les universités, les hôpitaux : Le coût d'un déficit de 400000 emplois au Québec — Expos, Montréal Symphony Orchestra, Universities, Hospitals: The Cost of a 400,000-Job Shortfall in Québec / Marcel Boyer

96c-1 Peut-on créer des emplois en réglementant le temps de travail? / Robert Lacroix

95c-2 Anomalies de marché et sélection des titres au Canada / Richard Guay, Jean-François L'Her et Jean-Marc Suret

95c-1 La réglementation incitative / Marcel Boyer

94c-3 L'importance relative des gouvernements: causes, conséquences et organisations alternative / Claude Montmarquette

94c-2 Commercial Bankruptcy and Financial Reorganization in Canada / Jocelyn Martel

94c-1 Faire ou faire faire : La perspective de l'économie des organisations / Michel Patry

\section{Série Scientifique / Scientific Series (ISSN 1198-8177)}

2000s-47 Économétrie, théorie des tests et philosophie des sciences / Jean-Marie Dufour

2000s-46 Factor Analysis and Independent Component Analysis in Presence of High Idiosyncratic Risks / Thierry Vessereau

2000s-45 Aspects non linéaires du marché dea actions français / Thierry Vessereau

2000s-44 Étude du modèle d'évaluation par arbitrage sur le marché des actions suisses / Thierry Vessereau

2000s-43 Habit Formation with Recursive Preferences / Aylin Seckin

2000s-42 Habit Formation: A Kind of Prudence? / Aylin Seckin

2000s-41 Consumption with Liquidity Constraints and Habit Formation / Aylin Seckin

2000s-40 Consumption-Leisure Choice with Habit Formation / Aylin Seckin

2000s-39 Consumption with Habit Formation / Aylin Seckin

2000s-38 Consumption with Durability / Aylin Seckin

2000s-37 Le financement des biens publics par des contributions volontaires: Une évaluation à l'aide de l'économie expérimentale / Claudia Keser

2000s-36 Conventions and Local Interaction Structures: Experimental Evidence / Siegfried K. Berninghaus, Karl-Martin Ehrhart et Claudia Keser

2000s-35 Strategically Planned Behavior in Public Good Experiments / Claudia Keser

2000s-34 Why Do Experimental Subjects Choose an Equilibrium which Is Neither Payoff Nor Risk Dominant? / Claudia Keser et Bodo Vogt

2000s-33 The Measurement and Antecedents of Turnover Intentions among IT Professionals / Guy Paré et Michel Tremblay

2000s-32 Can the Theory of Incentives Explain Decentralization? / Michel Poitevin

\footnotetext{
* Vous pouvez consulter la liste complète des publications du CIRANO et les publications elles-mêmes sur notre site Internet à l'adresse suivante :
}

http://www.cirano.umontreal.ca/publication/documents.html 